\section{4. ガ}

\section{1 天然ガス開発利用の動向}

\subsection{1 天然ガス開発の動向}

\section{1. 概 況}

世界の天然ガス生産は，原油生産に伴なう随伴ガス を別にしても，年々着実に増加している。

エネルギー消費国が1973年の石油危機に端を発し て, 脱石油の方針を打ち出しながらも，原子力の伸び 悩及，代替エネルギーの開発の見込々薄から，石油依 存が替兄られない見通しのなかで，天然ガスの開発， 利用が大きく浮上してきて和り，わが国の場合も一層 その感が深い。

こうして，産ガス国，消費国双方とも，天然ガスは エネルギー市場に打いて石油製品と同格に扱われるよ らになり, 過去の余剩物もしくは副産物という概念を 完全に払拭するに至った。加光るに最近の傾向では天 然ガスにプレミアムバリューを付けるようになり，急 激な価格上昇を続けて高価格時代に入ってきた。この ような事情から, 資源保有国での価值観も变わって, 天然ガスの高度利用というよりはむしろ資源の温存政 策に転ずるなど，開発政策の局面にも大きな変化を生 じている。

\section{2. 生産量と埋藏量}

表 4-1 亿示すように，世界の天然ガス生産量は 1 兆 3,557 億 $\mathrm{m}^{3}$, 埋蔵量約 63 兆 $\mathrm{m}^{3}$ (原油換算 630 億 $\mathrm{k} l$ )

\section{表 4-1 世界の天然ガスの生産量と埋蔵量}

\begin{tabular}{|c|c|c|c|}
\hline & 地域 & $\begin{array}{c}\text { 生産量 } \\
\left(1975 \text { 年, } 10^{6} \mathrm{~m}^{3}\right)\end{array}$ & $\begin{array}{c}\text { 埋藏量 } \\
\left(\begin{array}{c}1976 \text { 年 } 1 \text { 月 } 1 \text { 日, } \\
10^{9} \mathrm{~m}^{3}\end{array}\right)\end{array}$ \\
\hline 中 & 東 & 58,273 & 15,255 \\
\hline ア & ジ & 23,126 & 3,159 \\
\hline & ーロッパ & 171,128 & 4,782 \\
\hline T & フリカ & 11,382 & 5,866 \\
\hline 北 & 米 & 676,483 & 7,601 \\
\hline 南 & 米 & 49,050 & 2,562 \\
\hline 共 & 産 圏 & 366,342 & 23,647 \\
\hline & 計 & $1,355,784$ & 62,872 \\
\hline
\end{tabular}

資料 : International Petroleum Encyclopedia, 1976
で， R/P は約47年となっている。

主要生産国であるアメリカの減退傾向にもかかわら ず, 生産量の増勢は他の地域での発展を示している。 さらに，本年の特長としてあげられるのは, 天然ガス のほかに油・ガス田に副産する天然ガス液化物 (Natural Gas Liquid) と LPG の生産と利用に対する関心 がにわか強まってきたことである。開発途上国に属 する産ガス国での天然ガスプラント建設の 殺到があ り, 北海でもブレント油田なぞ, この領域からの生産 が大きく注目されている。

このような傾向を反映して, 産ガス地で従来焼棄さ れていた天然ガスの有用性が高まり,むしろ再圧入用 として活用する傾向が強まっている。

\section{3. 天然ガスの主要生産地域の概况}

1) アメリカ

アメリカでは, 年々天然ガスの供給不足が深刻化し て扣り, 殊㳊冬から本年初にかけて異常寒波に見舞 われ，26パーセントの供給カットなど事態は悪化し， 異例の大統領による緊急天然ガス法の制定, 発動むな された。

供給力増大のために, 価格引上げなど刺载策をとっ てはいるものの, 期待されている外縁大陸棚の開発も 意の如く進まず, メキシコ湾一帯に 160 基の海洋掘削 リグが稼動しているが, 有力な新発見と供給力増大の 寄与にも限度があるとされている。

アメリカの資源量, 生産と供給力補壃の対策の推移 を図 4-1 に示す。

2) 西欧 (E C)

最大の供給ソースであるオランダのフローニンゲン ガス田の生産, 輸出の抑制方針への転換にもかかわら ず, 北海からの大陸への新しい受入れ（エコフィスク ガス田から年間 30 億 $\mathrm{m}^{3}$ 導入の実現) もあって, 順調 な生産と消費の増大をみている。

現在の EC の体制下では，極力域内資源の 温存を はかるため域外から輸入に依存する方針を打出して抹 り，表 4-2 の需給見通しにもあるように，その目標を 域内と域外を半々に保つ政策を指向している。

3) ソ連

豊富な埋蔵に恵まれて, 生産, 消費とも急増してい 


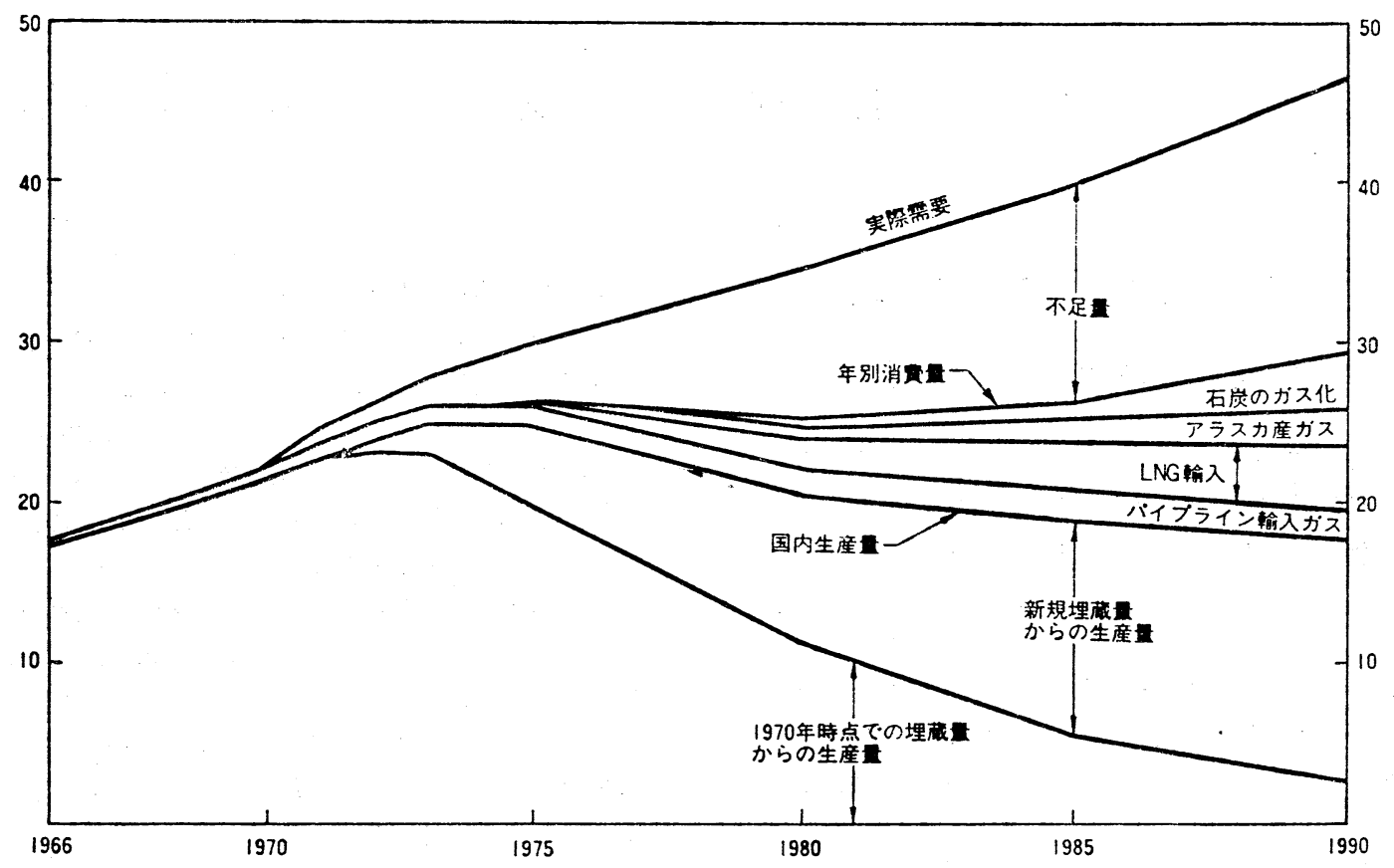

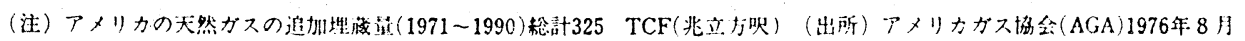

図 4-1 アメリカの天然ガス需給バランス (48州)

表 4-2 EC の天然ガス需給見通し (100万 $\left.\mathrm{Nm}^{3}\right)$

\begin{tabular}{|c|c|c|c|}
\hline & 1974実績 & 1980 & 1985 \\
\hline 費 & 164,000 & 245,700 & 304,200 \\
\hline 使用可能量 & 164,000 & 251,500 & 314,500 \\
\hline 国内生産 & 117,000 & 152,500 & 157,500 \\
\hline 輸 入 & 47,000 & 99,000 & 157,000 \\
\hline オラン ダ & 43,400 & 59,000 & 59,000 \\
\hline 北 海 & - & 15,000 & 20,000 \\
\hline y 連 & - & 10,000 & 15,000 \\
\hline アルジェリア & 1,800 & 12,000 & 30,000 \\
\hline $1 \quad$ ラ & - & - & $30,000(a)$ \\
\hline $\begin{array}{l}\text { そ(リビアなど } \\
\text { (リ他 }\end{array}$ & 1,800 & 3,000 & 3,000 \\
\hline
\end{tabular}

(a) イランについては同国の輸出見込み 平均量を採用

出所 : SOBEMAP

るが，最近は技術的問題と資器材入手難のほか，供給 ソースが漸次東部に移るため，伸び悩みの状態にある といわれる。

事実, イラン, アフガニスタンなどからの輸入が輸 出を上まわって扣り, 西欧への輸出にしらても開発器 材，パイプライン用鋼管を見返りにするなど，むしろ 需給バランスに力を注いでいる。
現在では，当初の目標を若干抑兄，1980年の生産目 標として, 5,000〜6,000億 $\mathrm{m}^{3}$ の数字をあげているも のの, 早晚アメリカを凌駕する天然ガス普及国に成長 することは確実である。

4）中東，北アフリカ諸国

原油に副産する随伴ガスを別としても，イランの海 陸に淤け大ガス田の発見, チュニジアの海洋ガス田 の発見など，天然ガス資源量の増加はいちじるしい が，上述の随伴ガスの有効利用に熱意をみせているほ かはむしろ資源の温存政策を強めている。

したがって，西欧，米国などへの天然ガス輸出もパ イプライン, LNG とも技術的問題, 価格調整の困難 から漸次タイト化の傾向にあり, 原油にみられる資源 戦略の局面を露呈するに至っている。

\section{4. 日本の開発状況}

最近, 陸域の構造性ガス鉱床の新発見がなく, 開発 の新しい動きはないが, 水溶性ガス鉱床の開発につい ては地盤沈下問題を解放する新方式の開発が提供され ており, 比較的恵まれたこの種の資源の再開発に関心 が高まってきている。

一方, 海域ではわが国最初の本格的な大陸棚油田で ある阿賀沖油・ガス田（原油换算 1,000 万 $\mathrm{k} l, 90 \%$ が天然ガス）が51年 9 月半ばから原油 $600 \mathrm{k} l / \mathrm{d}$ ，ガス 
180 万 $\mathrm{m}^{3} / \mathrm{d}$ の生産を開始して扣り, 供給力増加に大 きく寄与している。

さらに，51年末から年初にかけて, 新潟沖, 北海道 日高沖，東北太平洋岸海域の久慈沖，八戸沖にそれぞ れ新鋭リグを駆使しての試掘が行なわれており，引き 続いて北海道周辺海域, 東北裹日本海域拉よび九州南 西海域に大々的な試掘活動が開始される機運にある。 したがって, 阿賀沖に続く第 2 , 第 3 の華々しい開発 動も十分期待されよう。

\section{5. 将来の展望}

相対的な R/P の帰結からも，原油に代替する天然 ガスの開発が増勢を続けることは確実であるが，一方 開発と市場が直結するようになった今日, パイプライ ン建設もしくは LNG 交易の問題点も浮上してきて 怙り，有用市場の成立いらなれば産ガス国と消費国と の協調いかんが開発の最大の指標となろう。この面の 打開策の一つとして, 洋上生産プラントの検討もすで に始まっている。

どちらかといえば，余剩物もしくは原油生産時の厄 介視された天然ガスも有限の資源としてのイメージに 脱皮した時代を迎えた感が深い。

\subsection{2 天然ガス利用の動向}

昭和48年の OPEC 諸国の原油価格の值上げによる 石油危機を契機として世界はインフレーションの波に 押し流され，これに対処するために昨年のわが国経済 は世界経済の沈滞による不況を克服し安定生長の軌道 にのせることであった。

幸い夏頃までは輸出が好調であったことが原因して 経済は回復の軌道に乗ったものの後半に至り設備投 資, 個人消費等内需の不振等により景気回復は著るし く停滞し，いわゆる“中だるみ”の足踏状態を呈する にいたった。それに加えて，51年12月の OPEC 諸国 の原油価格 5〜10\% に及ぶ再度の值上げは景気回復 を遅らせる結果となった。

このような情勢下に和いて昭和51年の天然ガスは燃 料および化学原料として重要な産業であることに鑑 及，国をはじめとし各企業は探鉱・開発拈よび生産に 積局的な努力が払われたにもかかわらず探鉱の成果は 上らず，ただ生産については昭和51年 9 月 27 日から阿 賀沖ガス田に执いて原油叔よび天然ガスの生産が開始 され，日本近海の大陸棚に执いて初めて本格的な油・ ガス田が稼行されるに至った。

LNG の輸入は，前年に引続きアラスカより508, 690 $\mathrm{t}$ (1月〜 7月), ブルネイより $2,816,636 \mathrm{t}$ (1月〜 7 月）と順調に行われ，東京抢よび大阪地域に和ける 都市ガス用原料として約 14.2 億 $\mathrm{m}^{3}$ (1月〜 6 月) ま た火力発電用燃料として 約 25.7億（1月〜 6 月）が 利用された。

現在（1976年 1 月 1 日）世界の天然ガス埋蔵量は約 62.9 兆 $\mathrm{m}^{3}$ で前年に比して約 $3.6 \%$ 増加したが，新 地域に和ける天然ガス鉱床の報道はされなかった。

天然ガスの埋蔵地域とその占める割合は, ソ連 $36.0 \%$, 中近東 $24.3 \%$, 北アメリカ $12.1 \%$, アフリ カ $9.33 \%$, 西欧 $7.6 \%$, アジア・大洋州 $5.0 \%$ と》 連が最も多くついで中近東, 北アメリカの順位となっ ている。アメリカに拈いては, 1975年の天然ガス生産 量 5,796 億 $\mathrm{m}^{3}$ に対し確認埋蔵量は 6.09 兆 $\mathrm{m}^{3}, \mathrm{R} / \mathrm{P} 14$ と過去 5 か年間埋蔵量は連続して減退したと AGA から発表された。

1975年に和ける世界の天然ガス 生産量は 約 1.36 兆 $\mathrm{m}^{3}$ で $\mathrm{R} / \mathrm{P}$ は46となり，熱量換算原油の $52 \%$ 飞相 当する生産となった。

ガス体エネルギーは, 現在一次エネルギー需要にお いてアメリカで $30 \%$ 以上, 欧州諸国でも約 10\% 程 度の割合を占め, 石油危機以後は欧州諸国はガス体エ ネルギーを $20 \%$ 程度まで拡大する政策をとってい る。

一方わが国の現状は，ガス体エネルギーは都市ガ ス, LNG などを合わせても数\% の割合を占めるの に過ぎないので石油代替エネルギーとして原子力とと もに LNG の積極的導入と活用をはかるべき方向に ある。

国内の天然ガス生産量は約 24.9 億 $\mathrm{m}^{3}$ と前年に比 較して $2.35 \%$ ，販売量は約 24.3 億と 前年より 2.73 \%，それぞれ増加を示した。

産業別販売利用状況は表 4-3 亿示すと扮り化学工業 用 $44.83 \%$ ，都市ガス用 $26.92 \%$ ，その他製造業 14.64 $\%$, 発電用 $13.64 \%$ と発電用がわずか増加したほか

\section{表 4-3 天然ガスの産業別販売量}

\begin{tabular}{|c|c|c|}
\hline 産 業 別 & 販売量 $\left(1,000 \mathrm{~m}^{3}\right)$ & 構成比(\%) \\
\hline 化 学 工 業 & $1,087,071$ & 44.83 \\
\hline その他の製造業 & 352,557 & 14.54 \\
\hline 発 電 業 & 330,783 & 13.64 \\
\hline 都市ガス 業 & 652,763 & 26,92 \\
\hline 運 輸 業 & - & - \\
\hline の 他 & 1,871 & 0.07 \\
\hline 計 & $2,425,045$ & 100.00 \\
\hline
\end{tabular}


は概ね前年と同様の割合であった。

\section{1. 化学工業用}

石油化学工業は, 石油危機による原料価格の高騰の 影響を直接的に受けいまだ回復するに至らず新たな目 標を持ち得ない状態にある。こうした状況下に扬いて 化学工業に使用された天然ガスは約 10.9 億 $\mathrm{m}^{3}$ で大 部分がメタノール，アンモニアに一部が化学薬品の製 造に用いられた。

わが国のメタノール製造会社は 6 社で内天然ガスを 原料とするもの 3 社により $576,791 \mathrm{t}$ が生産され全国 生産量 $951,180 \mathrm{t}$ 中の $60.6 \%$ を占めブタンを原料と する工場が操短を余儀なくされたのに天然ガスを原料 とする工場は順調な操業が続けられた。また, 後期に いたり需給の関係上カナダおよび韓国から一部輸入が 行なわれた。

アンモニアの生産は前年に引き続き厳しい状況下に あり天然ガスを原料とするもの $251,500 \mathrm{t}$ と全国生産 量 2,626,329t 中の約 $9.58 \%$ を生産したに止まり, 二次製品として硫安および尿素などが製造された。

\section{2. 都市ガス用}

都市ガスは国民生活に密接するエネルギーで生活の 向上と都市の発展とともにその需要は年々増加してき たが，石油危機による原料価格の值上りに影響されて 都市ガス事業の活動は低調で需要家数就よびガス販売 量とも年間を通じて伸び悩みの傾向にあった。

昭和51年末に括ける全国のガス事業者数は 255 , 需 要家数 1,438 万戸, 販売ガス量 75.7 億 $\mathrm{m}^{3}(10,000 \mathrm{kcal}$ 換算）と前年に比し 需要家数は $4.18 \%$, 販売ガス量 は $8.43 \%$ の増加にとどまり, ガス販売量のうち天然 ガス量は約 6.53 億 $\mathrm{m}^{3}$ と $8.6 \%$ を占めた。

アラスカおよびブルネイよりの輸入 LNG は都市 ガス原料として $1,446,429 \mathrm{t}$ が利用された。

\section{3. 発電用}

発電用燃料として新潟県下に扣いて 約 3.3 億 $\mathrm{m}^{3}$ が 利用され，9月末より生産を開始した阿賀沖ガス田の 生産ガスは大部分が東北電力(株)新潟火力発電に供給 されている。

輸入 LNG は都市ガス原料として利用されたほか は横浜, 千葉拉よび大阪地域の火力発電用燃料として $2,568,955.000 \mathrm{~m}^{3}$ ( 1 月〜 6 月) が利用された。なお, 昭和 49 年预よび50年に拈ける火力発電用燃料として消 費された LNG の量はそれぞれ $3,472,627.000 \mathrm{~m}^{3}$, $4,670,539,000 \mathrm{~m}^{3}$ (液化天然ガス気化率 $1,400 \mathrm{~m}^{3} / \mathrm{t}$ ) であった。

\section{4. その他の製造業}

鉄鋼業および一般加熱用燃料として利用されたが， 陸域に怙ける新規がス田の発見がなく，一方地盤沈下 に伴う水溶性ガスの生産制限などの措置のため生産量 の不足をきたし前年に比較して $6.6 \%$ 減の約 3.53 億 $\mathrm{m}^{3}$ に過ぎなかった。

以上天然ガス利用の動向について述べたが，資源エ ネルギーの有限性があらためて現実のものとして再認 識され，これまでのよらな高度成長が許されない状況 が広く一般に広がった現在, 早急なェネルギー資源の 安定的供給確保をはかる必要がある。

\section{2 都市ガス需給とガス原料の動向}

\section{1. はじめに}

ガス体エネルギーは現在, 一次エネルギー需要にお いてアメリカで $30 \%$ 以上, 欧州諸国でも $10 \%$ 程度 のシェアーをもち, 特に石油ショック以後は欧州諸国 についてみると, 各国の総合エネルギー政策に执いて ガス体エネルギーを $20 \%$ 程度まで拡大することを目 ざしている。

わが国の現状をみると，ガス体エネルギーは都市ガ ス, LNG などを合わせても数\% のシェアーしか持 つていない。しかし, 総合エネルギー調査会答申（昭 和50年 8 月）によれば, 昭和 48 年度の石油依存度 77 $\%$ を昭和 60 年度に $63 \%$ まで低下させることを目標と して揭げ，石油代替エネルギーとして原子力と共に LNG の積極的活用を図ることとしている。

特にクリーンェネルギーである LNG 拡大は，ガ ス体エネルギーの拡大を前提としている。

ガス体エネルギーは, $\mathrm{NO}_{x}, \mathrm{SO}_{x}$ 対策などの環境 保全面で優れた特性を持ち, 取り扱いやすく高カロリ 一であること等のプレミアム特性を持っている反面, ガス原料扣よび製造, 流通などの供給形態は多様であ り，これまでガス体エネルギーとしての総合的な検討 はあまり進められていなかった。

このような背景を踏えて, 都市ガス事業の現状と将 来について展望してみる。

\section{2. 都市カスス事業の現状}

\section{1 企業規模の格差}

一般ガス事業者は昭和 51 年 4 月現在 255 事業所であ り, そのらち私営は 180, 公営は75である。

これらガス事業者には東京瓦斯, 大阪瓦斯, 東邦瓦 斯などの大手企業がある反面, 大半のガス事業者は一 市町村のらちの市街化地域のみを対象としているるの 
表 4-4 資本金, 従業員数別事業者数

（昭和51年 4 月末現在）

\begin{tabular}{|c|c|c|c|c|c|c|}
\hline $\begin{array}{l}\text { 従業 } \\
\text { 資数 } \\
\text { 金額 } \\
\end{array}$ & $\begin{array}{l}\text { 10人 } \\
\text { 以下 }\end{array}$ & $\begin{array}{l}11 \text { 人 } \\
\text { 以上 } \\
50 \text { 人 }\end{array}$ & $\begin{array}{l}51 \text { 人 } \\
\text { 以上 } \\
100 \text { 人 }\end{array}$ & $\begin{array}{l}\text { 101人 } \\
\text { 以上 } \\
300 \text { 人 }\end{array}$ & $\begin{array}{l}\text { 301人 } \\
\text { 以上 }\end{array}$ & 計 \\
\hline $\begin{array}{c}3 \\
\text { 以 }\end{array} \frac{\text { 円 }}{下}$ & 6 & 26 & 2 & - & - & 34 \\
\hline $\begin{array}{l}3 \text { 千万円超 } \\
\underset{\text { 以 }}{5} \text { 千方年 }\end{array}$ & 13 & 30 & 5 & 1 & - & 49 \\
\hline $\begin{array}{l}5 \text { 千万円超 } \\
\underset{\text { 下 }}{\sim} 1 \text { 億円以 }\end{array}$ & 5 & 37 & 9 & - & - & 51 \\
\hline $\begin{array}{c}1 \text { 億円超〜 } \\
10 \text { 億円以下 }\end{array}$ & 1 & 10 & 13 & 11 & 3 & 38 \\
\hline 10 億円超 & - & - & - & - & 8 & 8 \\
\hline 私 営 計 & 25 & 103 & 29 & 12 & 11 & 180 \\
\hline 公 営 計 & 34 & 30 & 9 & 1 & 1 & 75 \\
\hline 合 計 & 59 & 133 & 38 & 13 & 12 & 255 \\
\hline
\end{tabular}

表 4-5 需要家数別事業者数(昭和 51 年 4 月末現在)

\begin{tabular}{|c|c|c|c|c|c|}
\hline & 私営 & 公営 & 計 & 構成比 & $\begin{array}{l}\text { 累 皘 } \\
\text { 比構成 }\end{array}$ \\
\hline 1,000 件以下 & 11 & 3 & 14 & 5.5 & 5.5 \\
\hline $\begin{array}{l}1,001 \text { 件 } \\
\sim 2,000 \text { 件 }\end{array}$ & 24 & 14 & 38 & 14.9 & 20.4 \\
\hline $\begin{array}{l}2,001 \text { 件 } \\
\sim 3,000 \text { 件 }\end{array}$ & 28 & 18 & 46 & 18.0 & 38.4 \\
\hline $\begin{array}{l}3,001 \text { 件 } \\
\sim 4,000 \text { 件 }\end{array}$ & 11 & 5 & 16 & 6.3 & 44.7 \\
\hline $\begin{array}{l}4,001 \text { 件 } \\
\sim 5,000 \text { 件 }\end{array}$ & 14 & 10 & 24 & 9.4 & 54.1 \\
\hline $\begin{array}{l}5,001 \text { 件 } \\
\quad \sim 10,000 \text { 件 }\end{array}$ & 32 & 13 & 45 & 17.6 & 71.7 \\
\hline $\begin{array}{l}10,001 \text { 件 } \\
\sim 50,000 \text { 件 }\end{array}$ & 43 & 11 & 54 & 21.2 & 92.9 \\
\hline $\begin{array}{l}50,000 \text { 件 } \\
\sim 100,000 \text { 件 }\end{array}$ & 6 & - & 6 & 2.4 & 95.3 \\
\hline $\begin{array}{l}100,001 \text { 件 } \\
\sim 300,000 \text { 件 }\end{array}$ & 7 & 1 & 8 & 3.1 & 98.4 \\
\hline $\begin{array}{l}300,001 \text { 件 } \\
\quad \sim 500,000 \text { 件 }\end{array}$ & - & - & - & - & - \\
\hline 500,001 件以上 & 4 & - & 4 & 1.6 & 100 \\
\hline 計 & 180 & 75 & 255 & 100 & 7 \\
\hline
\end{tabular}

注: 需要家数はメーター取付数である。

が多く，その供給区域は狭小であり，かつ企業規模は 小規模なものが圧倒的に多い。

因みに私営事業のう ち資本金 1 億円以上, 従業員 300 人を超える企業は 11 社, 全体の約 $6 \%$ にとどま り,また需要家数に执いて全事業者のうち10万件を超
表 4-6 主要地区別ガス普及状況

\begin{tabular}{|c|c|c|c|c|}
\hline 地区別 & 需要家数 & $\begin{array}{l}\text { 供給区域 } \\
\text { 内世帯数 }\end{array}$ & $\begin{array}{l}\text { 50年末 } \\
\text { 普及率 }\end{array}$ & $\begin{array}{l}\text { 49年末 } \\
\text { 普及率 }\end{array}$ \\
\hline $\begin{array}{l}\text { 東京瓦斯 } \\
\text { 京浜地区 }\end{array}$ & $5,053,802$ & $5,703,747$ & $88.6 \%$ & $88.6 \%$ \\
\hline $\begin{array}{l}\text { 東邦瓦斯 } \\
\text { 全 地 区 }\end{array}$ & 885,710 & $1,125,651$ & $78.7 \%$ & $77.0 \%$ \\
\hline $\begin{array}{l}\text { 大阪瓦斯 } \\
\text { 京阪神地区 }\end{array}$ & $3,628,199$ & $4,144,961$ & $87.5 \%$ & $88.0 \%$ \\
\hline $\begin{array}{l}\text { 広島ガ不 } \\
\text { 広島地区 }\end{array}$ & 153,916 & 280,971 & $54.8 \%$ & $54.0 \%$ \\
\hline $\begin{array}{l}\text { 西部瓦斯 } \\
\text { 福岡地区 }\end{array}$ & 207,789 & 283,760 & $73.2 \%$ & $71.7 \%$ \\
\hline その他地区 & $3,870,664$ & $7,740,620$ & $50.0 \%$ & $49.2 \%$ \\
\hline 国 & $13,800,080$ & $19,279,710$ & $71.6 \%$ & $70.8 \%$ \\
\hline
\end{tabular}

えるものは12事業者, 約 $4.7 \%$ を占めているにすぎ ない(表4-4〜5)。

またガス事業は同じ公益事業である電気事業に比べ てもその普及率は低く，50年度についてみると供給区 域内に持ける普及率は全事業者で $71.6 \%$ とすぎな い(表 4-6)。

このように普及率の一般的な低水準に加えて, 大手 と小規模企業との普及率格差もまた極めて大きい。

\section{2 需要形態の特異性}

ガス事業の需要は家庭用が大半を占め, 需要家件数 では 94\%，販売量では 64\%を占めている。

このため, ガスの需要の負荷変動も, 主として家庭 用のそれを反映することとなり, 電力需要の負荷パタ ーンとは極めて対照的である（表 4-7〜 8, 図 4-2）。

\section{3 他燃料との競合}

ガスはあらゆる需要分野に沶いて他然料との競合が 激しく, 完全独占に近い電力とは全く異なっている。

表 4-9 に示すように，家庭用においては，プロパ ン, 灯油などの石油系製品和よび電気との競合があ り, その他の需要分野においてもプロパン, 灯油のほ かブタン，重油などとの競合が激しい。

\section{4 多様なガスの種類}

都市ガスの原料は，現在のところ 石油系ガスが 43 $\%$, 天然ガス（含 LNG）が $34 \%$, 石炭系 ガス $22 \%$ がを占めて扣り, このような原料の多様化はガスの安 定供給に資するものといえる。

しかしながら事業者間で使用原料が異なることに加 えて，同じ原料を使用しても製造方法により種々の然 焼性のガスが製造されるため, 現在わが国のガスの種 類は14種類にも及んでいる。

これは従来供給ガスの種類および然焼管理について 
表 4-7 年度末用途別需要家数の推移

（単位：1,000件）

\begin{tabular}{|c|c|c|c|c|c|c|c|}
\hline & \multirow{2}{*}{45} & \multirow{2}{*}{46} & \multirow{2}{*}{47} & \multirow{2}{*}{48} & \multirow{2}{*}{49} & \multirow{2}{*}{50} & 対 前 年 対 比 \\
\hline 用途 & & & & & & & $46 / 45 \quad 47 / 46 \quad 48 / 47 \quad 49 / 48 \quad 50 / 49$ \\
\hline 家庭用 & $\begin{array}{r}(94.0) \\
9,752.0\end{array}$ & $\begin{array}{r}(94.1) \\
10,462.5\end{array}$ & $\begin{array}{r}(94.2) \\
11,208.8\end{array}$ & $\begin{array}{r}(94.2) \\
11,952.2\end{array}$ & $\begin{array}{r}(94.3) \\
12,644.6\end{array}$ & $\begin{array}{r}(94.0) \\
13,096.0\end{array}$ & $\begin{array}{lllll}107.3 & 107.1 & 106.6 & 105.8 & 103.6\end{array}$ \\
\hline 商 業 用 & $\begin{array}{l}(4.6) \\
471.7\end{array}$ & $\begin{array}{l}(4.5) \\
505.6\end{array}$ & $\begin{array}{l}(4.4) \\
526.4\end{array}$ & $\begin{array}{l}(4.5) \\
569.3\end{array}$ & $\begin{array}{l}(4.5) \\
597.8\end{array}$ & $\begin{array}{l}(4.7) \\
653.9\end{array}$ & $\begin{array}{lllll}107.2 & 104.1 & 108.1 & 105.0 & 109.4\end{array}$ \\
\hline 工 業用 & $\begin{array}{r}(0.5) \\
53.6\end{array}$ & $\begin{array}{r}(0.5) \\
54.2\end{array}$ & $\begin{array}{r}(0.5) \\
54.5\end{array}$ & $\begin{array}{r}(0.4) \\
57.2\end{array}$ & $\begin{array}{r}(0.4) \\
57.9\end{array}$ & $\begin{array}{r}(0.4) \\
59.5\end{array}$ & 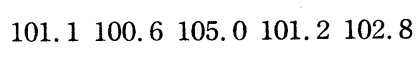 \\
\hline その他 & $\begin{array}{r}(0.9) \\
93.5\end{array}$ & $\begin{array}{r}(0.9) \\
98.2\end{array}$ & $\begin{array}{l}(0.9) \\
102.3\end{array}$ & $\begin{array}{l}(0.9) \\
108.6\end{array}$ & $\begin{array}{l}(0.8) \\
113.8\end{array}$ & $\begin{array}{l}(0.9) \\
122.4\end{array}$ & 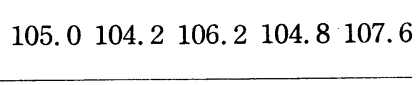 \\
\hline 計 & $\begin{array}{r}(100.0) \\
10,370.8\end{array}$ & $\begin{array}{r}(100.0) \\
11,120.5\end{array}$ & $\begin{array}{r}(100.0) \\
11,892.0\end{array}$ & $\begin{array}{r}(100.0) \\
12,687.3\end{array}$ & $\begin{array}{r}(100.0) \\
13,414.1\end{array}$ & $\begin{array}{r}(100.0) \\
13,931.8\end{array}$ & $\begin{array}{lllll}107.2 & 106.9 & 106.7 & 105.7 & 103.9\end{array}$ \\
\hline
\end{tabular}

注：（）内構成比

表 4-8 ガス販売量の推移 (単位: 100 万 $\left.\mathrm{m}^{3}\right)\left(1\right.$ 万 $\left.\mathrm{kcal} / \mathrm{m}^{3}\right)$

\begin{tabular}{|c|c|c|c|c|c|c|c|}
\hline 年 & \multirow{2}{*}{45} & \multirow{2}{*}{46} & \multirow{2}{*}{47} & \multirow{2}{*}{48} & \multirow{2}{*}{49} & \multirow{2}{*}{50} & 対 前 年 対 比 \\
\hline 用途 & & & & & & & $46 / 45 \quad 47 / 46 \quad 48 / 47 \quad 49 / 48 \quad 50 / 49$ \\
\hline 家庭用 & $\begin{array}{r}(64.4) \\
2,943.2\end{array}$ & $\begin{array}{r}(65.7) \\
3,261.3\end{array}$ & $\begin{array}{r}(66.3) \\
3,591.1\end{array}$ & $\begin{array}{r}(65.7) \\
4,015.8\end{array}$ & $\begin{array}{r}(64.6) \\
4,340.2\end{array}$ & $\begin{array}{r}(64.0) \\
4,543.6\end{array}$ & $\begin{array}{lllll}110.8 & 110.1 & 111.8 & 108.1 & 104.7\end{array}$ \\
\hline 商 業 用 & $\begin{array}{r}(19.2) \\
877.9\end{array}$ & $\begin{array}{r}(18.6) \\
924.7\end{array}$ & $\begin{array}{r}(18.4) \\
994.7\end{array}$ & $\begin{array}{r}(18.0) \\
1,099.7\end{array}$ & $\begin{array}{r}(17.6) \\
1,182.9\end{array}$ & $\begin{array}{r}(17.7) \\
1,257.9\end{array}$ & $\begin{array}{lllll}105.3 & 107.6 & 110.6 & 107.6 & 106.3\end{array}$ \\
\hline 工 業 用 & $\begin{array}{r}(10.6) \\
486.2\end{array}$ & $\begin{array}{l}(10.2) \\
505.9\end{array}$ & $\begin{array}{r}(10.1) \\
547.0\end{array}$ & $\begin{array}{r}(11.1) \\
679.1\end{array}$ & $\begin{array}{c}(12.4) \\
832.4\end{array}$ & $\begin{array}{c}(12.6) \\
891.9\end{array}$ & $\begin{array}{lllll}104.1 & 108.1 & 124.1 & 122.6 & 107.1\end{array}$ \\
\hline その他 & $\begin{array}{l}(5.8) \\
264.0\end{array}$ & $\begin{array}{l}(5.5) \\
270.7\end{array}$ & $\begin{array}{l}(5.2) \\
284.6\end{array}$ & $\begin{array}{l}(5.2) \\
321.6\end{array}$ & $\begin{array}{l}(5.4) \\
366.2\end{array}$ & $\begin{array}{l}(5.7) \\
403.1\end{array}$ & 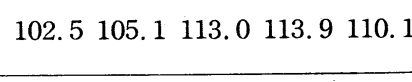 \\
\hline 計 & $\begin{array}{l}(100.0) \\
4,571.3\end{array}$ & $\begin{array}{l}(100.0) \\
4,962.6\end{array}$ & $\begin{array}{l}(100.0) \\
5,417.4\end{array}$ & $\begin{array}{l}(100.0) \\
6,116.2\end{array}$ & $\begin{array}{l}(100.0) \\
6,721.7\end{array}$ & $\begin{array}{l}(100.0) \\
7,096.5\end{array}$ & $\begin{array}{lllll}108.6 & 109.2 & 112.9 & 109.9 & 105.6\end{array}$ \\
\hline
\end{tabular}

注：（）内は構成比

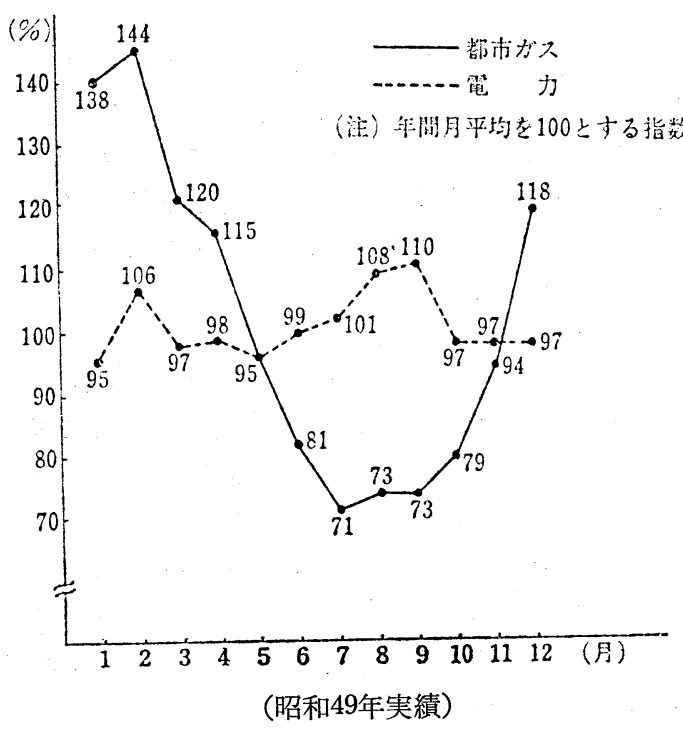

図 4-2 都市ガス・電力需要量月別変動
表 4-9 家庭用用途における競合

\begin{tabular}{|c|c|c|}
\hline 用途 & 競合燃料 & 競 合 機 器 例 \\
\hline 全 体 & $\mathrm{L} \quad \mathrm{P} G$ & $\left\{\begin{array}{l}(\text { ボンべ売り) } \\
(\text { 小規模導管 })\end{array}\right.$ \\
\hline 暖房用 & 電 合 & $\begin{array}{l}\left\{\begin{array}{l}\text { 灯油ストーブ } \\
\text { 灯油セントラルヒーティング }\end{array}\right. \\
\left\{\begin{array}{l}\text { 電気コタツ・パネルヒーター } \\
\text { ヒートポンプ式エアコン }\end{array}\right.\end{array}$ \\
\hline 温水用 & $\left\{\begin{array}{l}\text { 灯 } \\
\text { 電 }\end{array}\right.$ & $\begin{array}{l}\text { セントラルヒーティング } \\
\text { 電気温水器 }\end{array}$ \\
\hline 㕌房用 & 電 & 電気炊飯器・電子レンジ \\
\hline
\end{tabular}

は比較的各事業者の自主的な判断に委ねられていたこ とにもよるが，燃焼性が異なる場合にはこれに対応し た消費機器を変える必要があり, 消費者の利便, 保安 の確保などの観点から統合整理への検討が必要となろ 万(表 4-10 11)。

\section{3. 未来への展望}


表 4-10 原料別ガス事業者数（昭和 50 年 2 月実績）

\begin{tabular}{|c|c|c|c|c|}
\hline 原料 & 形 態 & 私営 & 公営 & 計 \\
\hline \multicolumn{2}{|c|}{ 液化石油ガス事業者 } & 60 & 7 & $\begin{array}{r}67 \\
(26.8)\end{array}$ \\
\hline ナフサガス & $\prime \prime$ & 26 & 6 & $\begin{array}{r}32 \\
(12.7)\end{array}$ \\
\hline 天 然 ガ．ス & "I & 11 & 42 & $\begin{array}{r}53 \\
(21.1)\end{array}$ \\
\hline $\begin{array}{l}\text { 液化石油ガス } \\
\text { ナフサガス }\end{array}$ & $\prime \prime$ & 34 & 7 & $\begin{array}{r}41 \\
(16.3)\end{array}$ \\
\hline その他原料 & $\prime \prime$ & 46 & 12 & $\begin{array}{r}58 \\
(23.1)\end{array}$ \\
\hline & & 177 & 74 & $\begin{array}{r}251 \\
(100 \%)\end{array}$ \\
\hline
\end{tabular}

注 : 1.「液化石油ガス事業者」「ナフサガス事業者」 「天然ガス事業者」は当該原料のみを使用して ガスを製造供給している事業者である。「液化 石油ガス，ナフサガス事業者」は当該原料のみ を組合わせて製造したガスを供給している事業 者である。

2.「その他原料事業者」は上記 1 以外の事業者 であってオフガス，石炭ガス， LNG 等または その組合せによりガスを製造，供給している事 業者である。

\section{1 都市ガスの役割}

都市ガスはクリーン・エネルギーであると同時に， 製造から消費にいたるまでの統合熱効率はきわめて高 く，また安定供給面に拉いても優れた実績を有してい る。

さらにパイプによる輸送形態は，消費地区に拉ける エネルギー貯蔵，陸送手段を必要とせず，都市の防 災，保安，輸送などの観点からも熱エネルギーの最適 供給システムである。

総合エネルギー調査会に护ける将来のエネルギー需 給計画では, 現在, 総エネルギー消費量の $4.8 \%$ (都 市ガス $1.8 \%$ ，LPG 3.0\%）にすぎないガズ体エネ ルギーが, 昭和60年度には約 $8 \%$ にまで拡大し，都
市ガスだけを考えても，中間答申の数字を展望すると $4 \%$, 約 300 億 $\mathrm{m}^{3}$ ( 1 万 kcal 換算) となり, 昭和 50 年度の販売量の 4.2 倍程度になるものと期待されてい る。

\section{2 都市ガスの需要動向}

このような旺盛な需要がいかなる分野に拈いて考え られるのかといら点については, 議論の分かれるとこ ろであるが，定性的にはつぎのことがいえよう。

\section{(1) 民生用需要}

民生部門に対しては, 所得水準の向上に伴って都市 ガス需要は増加していくものと予測される。

個人所得水準との相関により，この部門での伸び率 を予測すると，48〜60年に和ける平均伸び率は 8.4〜 $8.5 \%$ となり, 従来の 11 ～12\% よりも若干鈍化する ことになろら。

(2) ビル冷暖房用需要

環境へのインパクトや熱効率などのエネルギー特性 から, 今後の需要増に対しては電力が主体となってい くと予想されるが，発電所の立地制約ならびに夏季電 カピークの緩和に対して, 都市ガスが側面的に援助す ることになろう。

このことはエネルギー産業が互いに補完し合ら形で 設備の効率化を図るといら観点からの，将来のあるべ き姿を示唆して扣り，都市ガスも従来の傾向值に比べ て大きく伸びるものと思われる。

(3) 工業用需要

機能によって異なるが，都市ガスが他の液体燃料に 対して持っている相対的なプレミアム（経済的価值） を考えると, 今後の都市ガスの潜在需要は, 全エネル ギー需要の $2 / 3$ を占める産業用の加熱分野において特 に大きいといえよう。

すなわち，ガス体であることによる燃焼性，制御性 の良さ, プロセスの違いによる生産性の向上, 熱効率 の向上, 不良率, スケールロスの改善, 供給安定性,

表 4-11 原料別ガス生産購入量の推移 (単位 : 100 万 $\left.\mathrm{m}^{3}\right)\left(10,000 \mathrm{kcal} / \mathrm{m}^{3}\right)$

\begin{tabular}{|c|c|c|c|c|c|c|c|c|c|c|c|c|}
\hline 年度 & & 5 & & 46 & & 7 & & 18 & & 49 & 5 & 0 \\
\hline 項目 & 実 数 & $\begin{array}{l}\text { 構成比 } \\
\%\end{array}$ & 実数 & $\begin{array}{c}\text { 構成比 } \\
\%\end{array}$ & 実 数 & 構成比 & 実 数 & $\begin{array}{c}\text { 構成比 } \\
\%\end{array}$ & 実 数 & $\begin{array}{c}\text { 構成比 } \\
\%\end{array}$ & 実 数 & 構成比 \\
\hline 石油系ガス & 2,467 & 47.5 & 2,850 & 51.3 & 3,302 & 54.6 & 3,148 & 46.3 & 3,338 & 44.9 & 3,416 & 43.4 \\
\hline 石炭系ガス & 1,930 & 37.2 & 1,867 & 33.6 & 1,578 & 29.0 & 1,833 & 26.9 & 1,826 & 24.6 & 1,750 & 22.3 \\
\hline 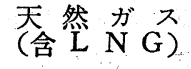 & 784 & 15.1 & 833 & 15.0 & 983 & 16.2 & 1,819 & 26.7 & 2,256 & 30.4 & 2,688 & 34.2 \\
\hline その 他 & 8 & 0.2 & 7 & 0.1 & 9 & 0.2 & 8 & 0.1 & 7 & 0.1 & 6 & 0.1 \\
\hline 合 & 5,189 & 100.0 & 5,557 & 100.0 & 6,052 & 100.0 & 6,807 & 100.0 & $7 ; 427$ & 100.0 & 7,860 & 100.0 \\
\hline
\end{tabular}


管理されたエネルギーであることによる作業環境の改 善といったことが正しく認識されることによって，利 用分野が拡大していくものと思われる。

特に, 乾燥 - 焼付, 焼鈍・熱処理, 鍛造・圧延, 小 型ボイラーの機能について, 他然料と十分競合でき, 60年度に打ける発電用加熱を除く産業用加熱然料の $10 \%$ 程度に当たる潜在需要が想定される。

したがって，今後の都市ガス需要に占める工業用の 割合は大幅に増加していくものと思われる。

3.3 都市ガス原料の動向

(1) LNG

LNG のクリーン・エネルギーとしてのメリットを 考えるならば，その価格が現在のように LS 原油と 対応して変化するかぎり, 今後も十分な需要が期待さ れて和り，当面需要面からの制約はないものと考古 る。

すなわち，将来のわが国への LNG 導入は，供給 の可能性にかかって拉り，供給があるならばその導入 は拡大していくものと思われる。

LNG プロジェクトに関しては，すでに導入が確定 しているものとして，55年に 2,160万t が確定してい るが，その他に現在，数多くのプロジェクトがある。

従来, 都市ガス事業では, 石炭, 原油などを主原料 として，製造ガスを中心に 発展してきたため，5,000 $\mathrm{kcal} / \mathrm{Nm}^{3}$ 程度の熱量のものを主体としてきたが, LNG が将来の有力なエネルギー資源として登場して きた現在では,このような旺盛な需要に対して, 都市 ガスを安定して供給するガス源を考えて, 大手ガス事 業者においては，LNG による天然ガス供給を実施中 であり，数年後には LNG を主力とした天然ガス供 給が確立することになろら。天然ガス供給方式のメリ ットとして以下のことが掲げられる。

(1) LNG はクリーンなエネルギー資源であること に加えて, ガス化効率が極めて高いことから理想的な ガス原料である。

(2) 天然ガス転換を行なうことにより熱量を高め, 既設導管, ホルダーなどの供給設備能力を倍増させ, 都市ガスの使命である安定供給が確保できる。

(3) LNG は製造, 輸送, 消費まで一環したプロジ ェクトであること, かつそのプロジェクトに巨額の資 金を要することから，長期にわたって大量の供給が継 続されなければ経済性を持たないといら特殊性を有し ており，相対的に供給の安定性は高いといえる。

一方，LNG と地方ガス事業者の関連については, $\mathrm{LNG}$ 導入が年間 400 万 $\mathrm{t} \sim 500$ 万 $\mathrm{t}$ といら規模を前提
として始めて経済性を追求できるものであり，これを 考慮すれば仮に全国ブロック毎に集約しても現在の都 市ガス需要量からして，ガス業界独自で導入すること は現実的に極めて困難な状況にある。

LNG 導入, 供給体制の確立は, 工業用などの大口 需要の確保を含めて導入規模に見合った需要をいかに 組織化するかが基本的要件であり, 受入基地の建設と 共にこのような組織化の前提となるパイプライン網の 整備をいかに実現できるかにかかっている。

(2) ナフサ, 原油

天然ガス供給用の主原料である LNG の受入パタ ーンは, 年間を通じて一定であり, 夏季・冬季の需要 差を調整するためには，多量かつ巨額の貯蔵タンクを 必要とする。したがって, LNG はベースロードとし て使用し, 季節的需要変動分は可能なかぎりナフサ, 原油などからの SNG でカバーするのが得策である。

都市ガスの代表的な送出パターンを参考として, 季節変動分を推定すると，約 $30 \%$ 弱となるので, $\mathrm{SNG}$ 製造能力としては, 年間供給量の 25 30\% が 一応の目安と考えられる。

(3) 石炭

サンシャイン計画の一環として, 石炭のハイカロリ 一ガス化研究を進めているが，60年までのフレームで は，石炭からの SNG は考兄られす，乙たがって現 在コ一クス炉用として使用している石炭処理量を当面 維持していくことになろう。

\section{4. おわりに}

都市に拈けるエネルギー政策は総合エネルギー政策 の方向を踏まえつつ, 生活水準, 環境の改善, 安全性 など幅広い視野に立って展開していく必要がある。

とりわけ都市ガスは, 従来から民生用エネルギー分 野で重要な位置を占めてきたが，その特性を見ると総 合熱効率が高いこと, 無公害であること, 都市の防災 の観点から安全性の高いこと, 供給の安定性が高いな どが指摘されている。

このような都市ガスの特性から, 都市ガスが液体燃 料に対して有するプレミアム（経済的価値）を分析す ると，(1)，都市ガスの有する経済的価值は，産業用加 熱分野に打ける多くの機能について大きく，特に，乾 燥・焼付, 焼鈍・熱処理, 金属溶解, ガラス溶解など の機能については, 利用者は都市ガスのメリットを十 分享受し得ると考えられる。(2) 都市ガスの有する経 済的価值のらち,「熱効率の良さ」「貯蔵の不要」「無 公害性」については, 利用者の経済性に利するだけで はなく, 省エネルギー, 安全, 環境改善という社会的 
効果につながるものであること。ということがい充 る。

したがって，今後民生用のみならず，産業用加熱分 野に叔いて都市ガスの比重の増大が見込まれ，またこ れを促進することが国全体として，今後のエネルギー 政策の方向である省エネルギー化，安定供給化澬す るものと考穴る。したがって，産業用加熱分野に括い て都市ガスへの転換をはかり，その利用を拡大してい くための環境づくりを早急に進める必要があるう。

また，民生用分野においても，今後一層の需要の増 大が見込まれる。

以上の諸要請に応えるために, 都市ガス事業の体制 整備，税金体系などを含めた総合的，長期的観点から 今後の都市ガス事業のあり方について諸検討を加兄, これに基づいた都市ガス政策の確立をはかることが肝 要である。

\section{3 合成ガス製造の動向}

\section{1. 一般情勢}

1.1 アンモニア

アンモニア業界は，未曾有の危機䍒面し，大きな 変革を必要とする時期にさしかかっている。能力ベー スでアンモニアの半分を消費する尿素は，その 7 割を 輸出に依存する極端な輸出産業であるが，50年以来の 需給関係の悪化とこれによる国際価格の暴落は51年に 入っても継続し, 回復の兆しは全く見られない。

50 肥料年度の尿素の輸出は, 前年比で量的に半分価 格的に $60 \%$ に減少し，51肥料年度は，さらにこれを 下回って和り，上期の輸出成約は，約 47 万 $\mathrm{t}^{1}$ で価格 はトン当り FOB 90 ドル台に低迷している。このた め国内のメーカーは生産調整を余儀なくされ，大型了 ンモニア・尿素プラントは軒並久操業短縮に追い込ま

\section{表 4-12 尿素, 硫安の生産量および輸出量}

\begin{tabular}{|c|c|c|c|c|}
\hline \multirow{2}{*}{ 肥年 } & 尿 & 素 & \multicolumn{2}{|c|}{ 硫 安 } \\
\hline & $\left(\begin{array}{l}\text { 告産 } \\
\text { (10 }\end{array}\right.$ & $\begin{array}{l}\text { 輸出 } \\
\left(10^{4} \stackrel{t}{t}\right)\end{array}$ & 生産 & $\begin{array}{l}\text { 輸 } \\
\left(10^{4} t\right)\end{array}$ \\
\hline 47 & 320 & 270 & 192 & 106 \\
\hline 48 & 312 & 212 & 190 & 84 \\
\hline 49 & 339 & 245 & 185 & 61 \\
\hline 50 & 193 & 124 & 194 & 67 \\
\hline 51 & (180) & (100) & (190) & (190) \\
\hline
\end{tabular}

肥料要覧 51 肥年は推定
れている。このような輸出環境の悪化の背景には, (1) 輸入原料価格の高騰により, 欧米の天然ガス原料 の設備とのコスト格差が拡がったこと。

(2) 肥料輸入国に叔ける自給体制が進行して招り，輸 出国に転じている国も出てきたこと。

（3） 48〜 49年の供給不安からの輸入国の過大輸入によ る在庫增と，これらの国の外貨危機。

(4) 一部の国に和ける干魀による需要の減少。

（5）世界的な不況による工業用アンモニアの肥料用へ の転向。

などが原因となっていることが挙げられる。これらの 中で，(1)および(2)は日本のアンモニア業界にとって最 も重大で，かつ本質的な問題である。1975年の TVA 質料に基づく，アンモニア・尿素の製造コスト競争力 の, モデル試算例を, 表4-13に示す2)。この試算によ ると日本の業界にとって最も脅威となっているのは $0.75 \$ / \mathrm{MCF}$ レベルの天然ガスを原料とする欧米の石 油危機以前に建設された設備で, 現在の国際相場はこ の工場渡価格付近になっているものとも考光らる。 また尿素は, 東欧諸国の外貨獲得政策や, 借款, 供与 等, 政治, 外交, 経済とのつながりの深い, 戦略物資 的な性格を帯びてきて扣り，これらによる日本への打 撃も大きい。中国につぐ市場であったインド市場は, 東欧拈よび中東諸国の攻勢により，日本はその大半を 失った。インドネシアは，自給体制の進行と，干魅に よる国内の需要減から，今年は輸出国に転じている ${ }^{3)}$ 。 さらに，ASEAN 加盟 5 か国は1985年までに，完全 自給化を目ざして，アンモニア・尿素の大型設備建設 を検討している4)。注目の中国の 13 基の大型アンモニ ア・尿素プラントの中， 2 基が51年暮れに完成し, 操 業を開始した ${ }^{5)}$ 。このような事態の中で, 通産省は, 産業構造審議会に対し，1970年代後半の化学肥料工業 とその施策のあり方に関する諮問を行なった。7月26 日付の答申の主なものに，対応策として，(1)需給の変 動に弾力的に対応できる操業体制の確立。(2)コスト上 昇による競争力の低下をカバーするため，重質油など への原料転換を積極的に進める。(3)硫安増加抑制のた め, 回収硫安の並産量を減少し, 副生硫安は現状に止 ぞめる，などを指摘している。現実に直面しているょ 一カーとしては，工業用アンモニアを安定に供給する ためには断続運転を行うわけにはいかず，低ロードで 運転を続けなければならないといら事情がある。しか しアンモニアプラントのハイパーコンプレッサーの運 転ロードには下限があり，このため各メーカーは，60 \%程度のロードで運転ができるようにコンプレッサー 
表 4-13 アンモニア, 尿素コストモデル試算例

（アンモニア $1,000 \mathrm{t} / \mathrm{d}$, 尿素 $1,667 \mathrm{t} / \mathrm{d}$ )

(既設：1973年操業開始, 新設 : 1978年操業開始)

\begin{tabular}{|c|c|c|c|c|}
\hline & \multicolumn{3}{|c|}{ 先進国工場 } & \multirow{2}{*}{$\frac{\text { 開発途上国工場 }}{\text { 新 設 N G }}$} \\
\hline & 既設NG & 新設 $\mathrm{NG}$ & 既設ナフサ & \\
\hline 原燃料価格* & 0.75 & 1.50 & 130 & 0.25 \\
\hline \multicolumn{5}{|c|}{ 設備，運転資金 $\left(10^{6}\right.$ ドル) } \\
\hline アンモニア工場 & 35 & 98 & 45 & 115 \\
\hline 尿素工場 & 27 & 65 & 35 & 73 \\
\hline 総投資額 & 62 & 163 & 80 & 188 \\
\hline \multicolumn{5}{|l|}{ 製造コスト（ドル/t $)$} \\
\hline アンモニア & 56 & 120 & 139 & 89 \\
\hline 尿＼cjkstart素 & 60 & 110 & 110 & 103 \\
\hline \multicolumn{5}{|c|}{ 工場渡価格**（ドル/t, 包装品） } \\
\hline アンモニア & 76 & 180 & 166 & 167 \\
\hline 尿 素 & 83 & 170 & 139 & 179 \\
\hline
\end{tabular}

* NG : \$/MCF, ナフサ: $\$ / \mathrm{t}$

** 投資利益 $(20 \%)$ を加えたもの

の改造を相ついで行なっている6)。またメラミンプラ ントの排ガスを受け入れている尿素プラントも, やは り断続運転ができず当事者は苦慮している7。一方尿 素の需要拡張のためのメラミンの増産や'), 集中生産 体制への再編成などもはかられている9”。

工業用アンモニアの需要は, 夏には回復の兆しが見

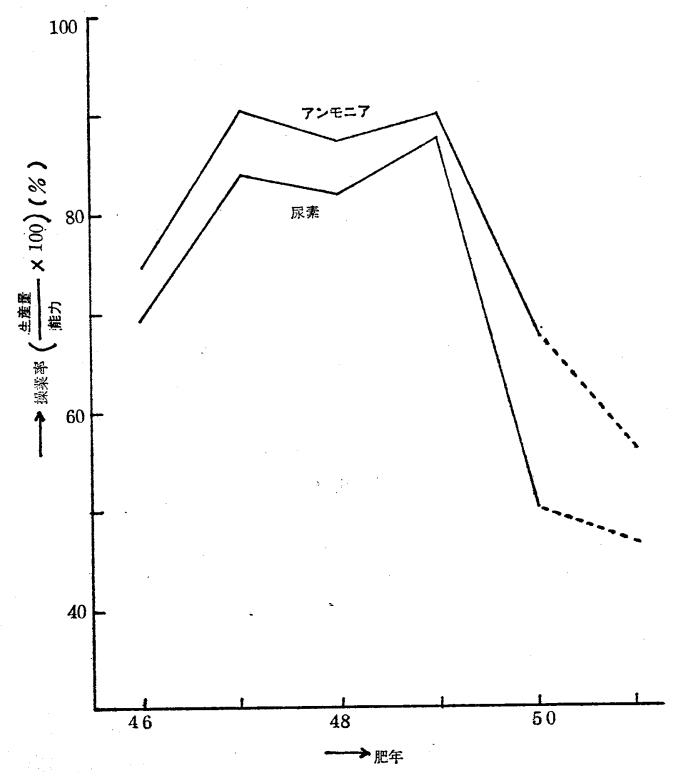

図 4-3 アンモニア，尿素プラントの操業率
えたものの,未だに完全には復していない。肥料用ア ンモニアの大幅な減少により, 工業用アンモニアの比 率は著しく増え, 10月には, アンモニアのほぼ全量が 工業用へ向けられるという異常な現象も見られた ${ }^{10) 。 ~}$ 液安の輸出は, 港湾設備や, 貯蔵タンクなど輸出体制 の整備も行なわれ期待されていたが ${ }^{11}$, 価格面での折 合いがつかず，3.7万t にとどまっている。

一方, 硫安の輸出は, 51肥料年度に入ってから好転 し，1月ですでに 155万t に達し12)，下期もかなりの 量が見込まれることから在庫も適正水準となり価格の 面でも回復に向らすのと見られている。

アンモニア製造プロセスについては，新しい発表は 少ない。Topsoe はアンモニア合成反応器内部構造の 改良を行ない, one-pass の転化率を向上させた ${ }^{13)}$ 。 インドネシアのプルタミナの, 海上アンモニア尿素プ ラントは，一部着手されていたが，その後陸上計画に 変更された ${ }^{14)}$ 。しかし海上プラントの開発は, 各国で かなり活発に行なわれている。

1.2 メタノール

不況による国内需要の低迷は 3 年目になるが, 夏ご ろからようやく回復の方向に向い，51年の需要は前年 を $25 \%$ 上回り 100 万 $\mathrm{t}$ 台に回復した ${ }^{15)}$ 。価格の引上 げも実現したが，依然として原料の差によるコストの 格差は大きく, 国内天然ガスを使用している三菱ガス 化学の $600 \mathrm{t} / \mathrm{d}$ プラント 2 系列が, フル操業を続けて 
表 4-14 メタノール需給推移 $\left(10^{4} \mathrm{t} /\right.$ 年 $)$

\begin{tabular}{ccccc}
\hline 年度 & 能力 & 生産 & 内需 & 輸出 \\
\hline 48 & 127 & 122 & 120 & 4 \\
49 & 127 & 106 & 105 & 1 \\
50 & 142 & 72 & 79 & -3 \\
51 & 142 & $(96)$ & $(104)$ & $(-8)$ \\
\hline
\end{tabular}

いるのに対し，輸入ブタンを用いる，東・西両メタノ ールセンターは, 計画減産による断続運転を続けてお り，大型化のメリットを享受できない状況になってい る。問題となっていた両センターからの, 出資会社 3 社の資本引揚げは, 東日本メタノールセンターは住反 化学, 西日本メタノールセンターは三井東圧化学の, 両運営会社がそれぞれ引取ることで決着した ${ }^{16)}$ 。日本 側からの出資比率が $50 \%$ あり, 第 3 センター的性格 の, 韓国の大成メタノール $(1,000 \mathrm{t} / \mathrm{d})$ が 4 月に完成 した ${ }^{17)}$ 。 8 月にリボィラーの熱交換器のトラブルがあ り，一時操業をストップしたが，12月から操業を再開 した。このため, 日本側のメタノール引取りも, 年内 は 2.5 万にとどまった $\mathrm{t}^{18)}$ 。注目されていた, モンサ ント社の技術によるメタノール法酢酸設備の計画は, 相次いで具体化の段階に入った。ダイセルは20万 $\mathrm{t} /$ 年 の規模で，54年に設備完成を予定して扣り ${ }^{19) ， ま た 日 ~}$ 本合成化学も別会社を新設してほぼ同じ時期に, やは り20万t/年 の企業化を計画している20)。一方，メタ ノールの需要の一つの柱となっていた DMT は, ポリ エステル繊維の原料転換にともない減少に向らため, 15 万t $\mathrm{t}$ 年 程度の需要のあった DMT 用メタノール は，かなり減少するものと見られている21。 ICI は, $5 \sim 7.5$ 万t/年 のメタノール SCP 設備を, ビリンガ ムに建設することを発表した。スタートは1979年末の 予定で, SCP $1 \mathrm{t}$ あたり，2t のメタノールを使用す る ${ }^{22)}$ 。ポーランドは, メタノールを自動車然料に混合 するテストを行ってきており，実用化する最初の国に なりそうである ${ }^{23)}$ 。モービルオイルは，ゼオライト触 媒を用いて，メタノールを1段でガソリンに転換する 技術を開発し，ニュージーランドに，1.1億ガロン/年 のプラントを建設する計画を発表した。操業開始は, 1980年の予定 ${ }^{24)}$ 。三菱ガス化学は, 自社技術のメタノ 一ル製造法について, 触媒と熱回収の一部を改良し $た^{25)}$ 。Davy Power Gas 社は, Celanese 社の, 操業 中の $1,800 \mathrm{t} / \mathrm{d}$ メタノールプラントを省エネルギー方 式に改造する契約を行なった。合成塔の熱回収を行な い, メタノール $1 \mathrm{t}$ 当り 2 円程度のコストダウンが計
れるとのこと ${ }^{26)}$ 。Chem System 社は， 3 相流動床式 メタノール合成法を開発中 ${ }^{27)}$ 。ソ連 ${ }^{28}$ およびアメリカ 29)で，超大型メタノールプラントが計画されている。

1.3 オキソ合成

オクタノールは, 国内の軟質塩ビの需要の好調に加 えて, 輸出が好調だったため, 需要は昨年を $12 \%$ 上 回る 19万t を記録した ${ }^{30)}$ 。ブタノールも需給が, 共 に昨年より 10 数\% 増加し，7万t 台を回復した ${ }^{31) 。 ~}$

協和油化は，四日市のオキソ法ブチルアルデヒド

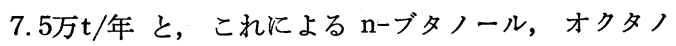
一ル各 1.5 万t/年 の増設を行なった ${ }^{32)}$ 。また三菱化 成は, ロジウム系触媒を用いる, 低温低圧法の技術を 確立し, 水島で 5 万t/年 のオクタノール 設備の 建設 に着手することとなった ${ }^{33)}$ 。三菱油化は, 四日市のレ ッペ法 n-ブタノール 設備をスクラップし, 三菱化成 のオクタノール設備の転用によるオキソ法 $\mathrm{n}$-ブタノ ールの製造を検討している ${ }^{34)}$ 。UCC は, ロジウム触 媒の新オキソ法による，13.6万t/年 のブチルアルデ ヒドプラントの抎張を行なった ${ }^{35)}$ 。ロジウム触媒を用 いるオキソ法は, 低圧であること, 異性体の生成比率 が少ないことなどから，今後の主流となるるのと見ら れている。

\section{4 その他}

排ガス中の $\mathrm{SO}_{x}$ に関する第 8 次 $\mathrm{K}$ 值規則が実施 された ${ }^{36)}$ 。 $\mathrm{NO}_{x}$ については, 新しい規制はなかっ た。

$\mathrm{NO}_{x}, \mathrm{SO}_{x}$ 除去に使用されるアンモニアは, 試算 段階で年 30 万 $\mathrm{t}$ 弱にのぼるるのとみられ, 今後のア ンモニアの需要構造が変化しかねない数量になる可能 性があるとされている ${ }^{37) 。 ~}$

\section{2. 合成ガス原料}

アンモニア, メタノール用合成ガス原料は, ナフ サ, ブタン, 天然ガスで大部分を占め, 能力ベースの 構成比率は前年と変っていない。しかし，ナフサ，ブ

表 4-15 ガス源別アンモニア, メタノール能力

\begin{tabular}{|c|c|c|c|c|}
\hline & \multicolumn{2}{|c|}{ アンモニア } & \multicolumn{2}{|c|}{ メタノール } \\
\hline & $\left(10^{4} t\right)$ & $(\%)$ & $\left(10^{4} t\right)$ & $(\%)$ \\
\hline 天 然 ガ ス & 39.1 & 8.8 & 66.8 & 46.8 \\
\hline L $\quad$ P $\quad$ G & 101.6 & 22.9 & 59.4 & 41.6 \\
\hline ナ フ & 200.9 & 45.3 & 16.5 & 11.6 \\
\hline C $\mathrm{O} \quad \mathrm{G}$ & 5.3 & 1.2 & {[} & - \\
\hline 石油廃 ガス & 72.7 & 16.4 & 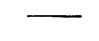 & - \\
\hline 原油・重質油 & 23.6 & 5.4 & {[} & - \\
\hline 計 & 443.4 & 100.0 & 142.7 & 100.0 \\
\hline
\end{tabular}


タンを原料とする設備と, 国内天然ガスのガス源を持 つ設備との競争力の差は大きく, これが直接操業度を 左右しているため, 生産量ベースの構成比率はかなり 異る。軽質油原料の高騰に対する，一つの施策として 重質油への転換が検討されており, 産業構造審議会答 申でも，これを指摘している。しかし，原料転換のた めの設備投資額が過大であるため, 現在のナフサ, LPG の価格体系では, アスファルトなどへの転換の 可能性は薄く, アンモニア, メタノール，酶酸など, 共同でガス化を考えていくべきであるという意見もみ られる

ナフサの，国内価格の 值上げ問題は，50年12月 か ら， 5 か月間にわたる長期交涉の末，4 月から新価格 29,000 円 $/ \mathrm{k} l$ とすることで括さったた ${ }^{39)}$ 。これは, ア メリカよりは大幅に高く, 51年10月現在の, 西欧の約 26,000 円 $/ \mathrm{k} l$, 韓国の 24,000 円 $/ \mathrm{k} l$ と比較しても, か なり割高である ${ }^{40)}$ 。ブタンは, 石油危機による価格の 上昇率がナフサよりる大きく，このためブタン使用の アンモニアメーカーは, 価格の高騰に苦慮していた が，長期的にみて，供給に安定性があるすのと見ら れ，見直されはじめている411。原料㘧よびェネルギー 転換としての, 石炭のガス化招よび液化は, 原料炭の 豊富なアメリカで盛んに行なわれている。しかし, ア メリカでは，石炭ガス化装置は投資額が大きすぎるた め, 技術者達の確信にもかかわらず，金融筋は危険性 が大きいと見ているともいわれている ${ }^{42)}$ 。天然ガスあ るいは石炭を, 産地でメタノールに転化し, これを輸 入して原料とする構想は, 日本産業技術振興協会の, メタノール大規模利用に関する T.A 報告書によれ ば，現状では非現実的であると指摘されている ${ }^{43)}$ 。乙 かし, 将来的には, メタノールは世界的な通商物資と なり,メタノールを原料とするプロセスは, 価格面で 優位性が出てくるものとみられている44。一方, 原子 炉などの熱を利用して水から水素を製造する技術に関 する発表は, 増々多くなっている。またこうして得ら れる水素の貯蔵法など, 周辺分野への展開も盛んであ る。製造コストに関する試算も若干発表された ${ }^{45)}$ 。水 素製造法として，スチームアイアンプロセスの再評価 も行なわれている46)。

\section{3. 合成ガス製造技術}

\section{1 ガス化}

スチームリフォーミング, 部分酸化とも, 新技術に 関する発表は少ない。Grande Paroisse 社と, Heurtey 社は, 流動床方式によるスチームリフォーミング法を 開発中で，今年中にこのプロジェクトを完成する予定
といわれる。エネルギーンストは固定床法と同程度で あるぶ，設備コストはやや高い。しかし炭素による触 媒層の詰りがないため, 重質油原料を使用することが できるとされている47)。Linde A.G は，スチームリ フォーミングによるガスから，高純度水素を回収する プロセスを開発した。また，BASF は，部分酸化ガ スから純粋な水素と一酸化炭素を得るプラントを建設

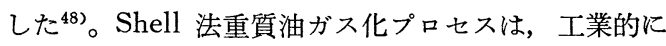
確立され，操業を行なっているプラントは，世界で150 基以上に達するといわれている49)。南アフリカの $\mathrm{AE}$ \& CI は, 石炭を原料とする 2 万t/年 のメタノール プラントをスタートした。石炭のガス化は, Koppers 一Totzek 法を採用し，メタノール 合成は，ICI 低圧 法による50。

\section{2 合成ガス精製}

川鉄化学は, アメリカテネコケミカルズ社 と共同 で, Cosorb プロセスによる転炉ガスがらの高純度一 酸化炭素回収システムの開発に成功した。この回収シ ステムにより, 従来燃料以外飞利用されていなかった 転炉ガスから，98〜 99\% の純度の一酸化炭素が分離 でき, 化学原料および還元ガスとしての利用が可能に なるとされている51)。

\section{3 脱硫怙よびティルガス処理}

Petrocarbon Development 社は，アンモニアプラ ントの合成ループのパージガスより，水素の大部分と 窒素の一部を回収する装置の設計を行なった。アンモ ニアを吸着除去後, ガスを部分凝縮させ, パージガス 中の水素の $95 \%$ が回収されるといら ${ }^{52)}$ 。海水を用い る煙道ガスの脱硫を行なう Flaks-Hydro プロセスに よる, 工業規模のプラントが, ノルウェーで稼動をは じめた ${ }^{53)}$ 。

\section{文献}

1）化学工業日報, 12.28

2) 桑原, 化学経済, 7 月号 p. 12

3）化学工業日報, 52.1 .26

4) 鈴木, 化学経済, 10月号 p. 2

5）化学工業日報, 52.1 .7

6) 同誌, 11.24

7) 同誌, 8.24

8) 同誌, 10.13

9) 同誌, 10.30

10) 同誌, 52.1 .7

11) 同誌, 2.4

12) 同誌, 52.1 .22

13) C.W, $5.26 \mathrm{p} 31$

14) C \& EN 10.4 p. 11

15）化学工業日報 52.2.10

16) 同誌, 12.23 
17) 同誌, 4.3

18) 同誌, 12.11

19) 同誌, 52.2 .5

20）日刊工業新聞，52.3.18

21）化学工業日報, 6.25

22) $\mathrm{ECN}, 10.1,1976$, p. 4

23) $\mathrm{ECN}, 12.31,1976$, p. 18

24）化学工業日報， 7.20

25) 同誌, 4.9

26) C. A, 4.30 p. 10

27) Hydrocarbon Processing, 55(11), 122

28）化学工業日報, 10.12

29) 同誌, 12.29

30) 同誌, 52.2 .5

31) 同誌, 52.2.2

32) 同誌, 3.23

33) 同誌, 4.20

34) 同誌, 10.6

35) C \& EN, 4.26 p. 25

36）環境公害新聞, 9.29

37）化学工業日報, 10.12

38) 板野，アンモニアと工業，30(1) 2 (1977)

39) 日本経済新聞， 4.23

40）化学経済, 3 月号 p. 85, (1977)

41）化学工業日報, 10.5

42) C \& EN, 11.1, 1976 p. 16

43）化学工業日報, 4.27

44) Chem. Marketing Reporter, 1, 26 p. 3

45) C \& EN, 3.15 p. 32

46) 中口, 石油学会誌, 20, 69 (1977)

47) C.W, 5.12 p. 71

48) Processing, Feb., p. 8

49) Oil \& Gos J., Japan. 12, 111

50) $\mathrm{ECN}, 5.21$ p. 32

51）日本経済新聞, 52.3.11

52) Processing, Nov., 1975 , p. 53

53) $\mathrm{C} \& \mathrm{EN}, 11.24$, [ 975 p. 20

\section{4 液化石油ガスの動向}

今日の LP ガス業界は需給・保安の両面で大きな 転換期を迎えている。

需給面では調査機関などを通じ，飛躍的な中東の LP ガス増産計画が伝えられ，今後 LP ガス業界とし てそれをどのように評価し，対応していくか，決断を 迫られるに至っている。また国内的には, こうした海 外情報を背景として LP ガス需給 5 か年計画が策定 され, 昭和 51 年度以降, 年率 $8.7 \%$ 伸びる 需要想定 が行なわれた。

一方保安面では48年から審議されていた高圧ガス取 締法, 同法省令の抜本的改正が, 約 3 年の年月を経て
公布・施行された。その後, 通産省は引続いて LP ガ ス一般消費者の保安の確保と取引の適正化を目的とす る LP ガス法 (正式には「液化石油ガスの 保安の 確 保拉よび取引の適正化に関する法律」）の改正に取り かかり, 今年末以降の公布をめざして, 現在, 積極的 な保安審議を行なっている。

\section{1. 拡大続ける需要規模}

さる 3 月 29 日開催された石油審議会で, 昭和 52 年度 を起点とする今後 5 か年間の石油供給計画を策定, こ れにより LP ガス需給計画が表 4-16 のと和り 52 年度 需要 1,279 万 $\mathrm{t} ， 56$ 年度 1,704 万 $\mathrm{t}$ と確定した。

今年度の石油供給計画・LP ガス需給計画は, 中だ るみの状況を脱し切れない経済界のなかにあって策定 され，52年度の燃料油内需は対前年度比 $5.9 \%$ の伸び が想定される一方, LP ガスについては $13.7 \%$ の増 加と, 51 年度の対前年度伸び率 $7.9 \%$ に比べ大幅な 上昇が見込まれている。またカ 5 か年間の平均伸び率 でみても, 然料油が $4.9 \%$, LP ガスが $8.7 \%$ の上 昇を想定して叔り，とくに LP ガスの需要の伸長が めだっている。

この LP ガス需要拡大の主な要因としては, 今後 とも鉄鋼用需要の大幅な增加が見込まれるほか，52年 度当初から新規に電力用需要が加わり, 大口用需要が 引続き増大する見通しにあるとともに，一般工業用需 要が景気の回復に合わせて, 昨年度の計画数量以上に 增加するすう勢にあり, 全需要の半数近くを占める家 庭業務用についても LP ガス用ふろバーナー, 湯沸 器など大型器具の普及率のアップに支觉られて, 今後 とす堅調な需要推移が続くことなどに基づいている。

一方この需要を賄う LP ガス供給については, 国内 生産量が(1)原油処理量が燃料油需要の伸びにみあう数 量で設定されている(2)石油化学工場の稼動率が依然と して低水準にあるとともに，工場内での LP ガスの自 家使用が増加しているなどにより，56年度 554 万t と 51 年度以降, 毎年度 $4.2 \%$ づつ上昇する予測が行なわ れる一方, 輸入についてはこの国内生産量の伸びと年 率 $8.7 \%$ の需要推移とのみあいから, 毎年度 $12.0 \%$ づつ上昇する見通しとなっている。このため国内生産 対輸入比率は, 51 年度 41 対 59 から 56 年度 32 対 68 まで輸 入比率が高まる状況となっている。

\section{2. 世界の LP ガス情勢}

世界の LP ガス資源情勢については 50 年中に和い ても，中東諸国で増産計画が相つぎ種々のジャーナリ ズムをにぎわしていたが，さらに51年に入り，各種調 查機関から独自の開発調査結果が明らかにされた。と 


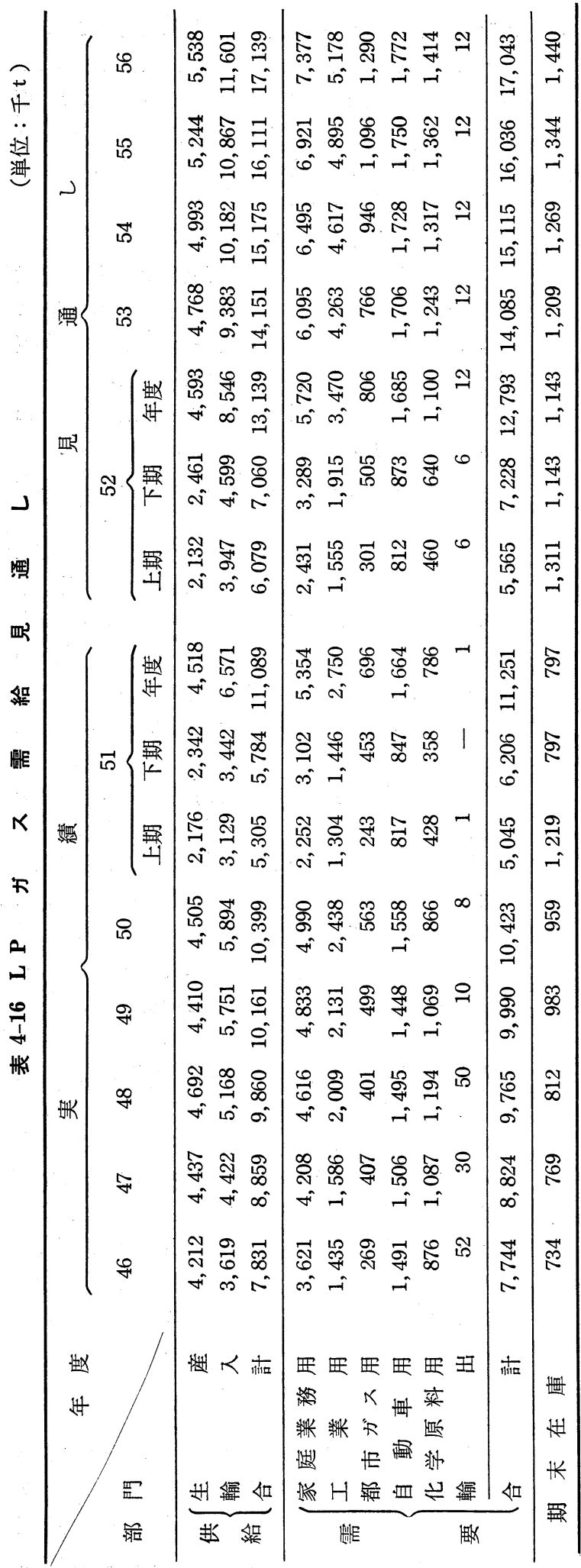

くに日本エネルギー 経済研究所は「LPG の国 際需給見通しとわが国への影響」をまとめた。 このなかで，1980年には中東だけで 3, 900万t に達し（最低の場合で 1,800 万t), このほかア フリカ, オーストラリア, インドネシア, 北 海, ベネズェラなどの輸出能力を加えると最低 で 2,700 万 $\mathrm{t}$ 。計画ど扮りだと 80 年には 4,800 万t， 85 年には 5,000 万 $\mathrm{t}$ に達するとし, 今 後, 大幅な LP ガス増産が期待されるとして いる。

一方，世界各国の需要についてはアメリカを はじめとする消費国が今後とも, 輸入合戦を展 開することが容易に予想され，とくに世界最大 の LP ガス消費国であるアメリカについては, 天然ガス生産の伸び恼みなどから， 今後，LP ガスの輸入政策への大幅な転換が予想されてい る。

こうした状況から，今後の LP ガス情勢は 世界的な LP ガス増産が伝えられるなかで, 世界最大の市場をもつアメリカのエネルギー政 策の動向が注目され，なりゆき次第ではわが国 の輸入状況が大いに影響されるところとなって いる。

\section{LP ガス関連法令の改正}

保安の確保に対する社会的な要請に基づい て, 現在, 通産省と LP ガス業界は LP ガス 関連法令の改正に前向きに取り組んでいる。

49年 7 月の高圧ガス括よび火薬類保安審議会 の保安答申に端を発した厳しい高圧ガス取締法 の改正措置は，51年 2 月の同法省令改正をもっ て一応終了し, 現在, LP ガス製造所 (製油 所, 輸入基地, 充てん所等) は同法に基づいて 設備などの抜本的な改善に全力をあげている。

また 51 年 8 月には, 先の高圧ガス抢よび火薬 類保安審議会は同審議会内に液化石油ガス消費 者保安分科会を設置し, LP ガス法の改正を目 的とする消費者保安の抜本的改革に着手した。 これは，LP ガス一般消費者の事故を絶滅する ため，通産大臣が高圧ガス括よび火薬類保安審 議会に液化石油ガス消費者保安体制のあり方を 諮問したことに基づくものであり，この結果， 同審議会は(1)販売業者および消費者等の保安確 保の責任のあり方(2)液化石油ガス消費設備の設 置段階での安全確保の方策(3)液化石油ガス販売 業者の調查義務のあり方と調查代行機関の位置 
づけ(4)液化石油ガス消費設備の使用管理方法の周知徹 底の方策(5)事故の損害賠償保険制度のあり方(6)液化石 油ガス器具などの製造段階での安全確保の方策(7)液化 石油ガス器具などの欠陥品対策のあり方(8)液化石油ガ スの組成分析と販売規制のあり方(9)バルク供給方式の あり方一などについて審議を開始するに至った。

52 年 6 月現在, 審議会答申を目ざして審議を継続中 であるが, 答申後のスケジュールとしては, 通産省が 答申を受けたのち，この答申に基づいて直ちに行政化 に移行するための準備を開始，今年末以降にも公布す る意向であるといわれている。

\section{4. 自主保安体制の早期確立}

LP ガス事故の件数を年度（10月 1 日〜翌年10月 1 日まで）みると, 図 4-4 のと拈り昭和46年度 852 件,
47 年度 862 件, 48 年度 932 件, 49 年度 915 件となって いる。49年度の統計から，どうして事故が起こったの かを原因別に分類すると， 6 割以上が消費者のちょっ とした不注意が原因になっている。

この事故原因を多い順にみると，ゴムホースに起因 する事故が筆頭で $20 \%$ を占めている。ついで遊びュ ックを誤って開いた事故, 元せんや器具コックの不完 全な閉止によるガスもれなどと続くが，消費者事故の 半数以上はホースと元せん，コックに関連している。

こうした状沉にある LP ガス事故は, LP ガス業 界の存立基盤を摇るがすことにもなりかねず，今日の LP ガス業界は事故撲滅に必死の努力を傾注してい る。すなわち，業界は先の LP ガス法改正にともな う各種保安審議・作業に積極的に協力するとともに,

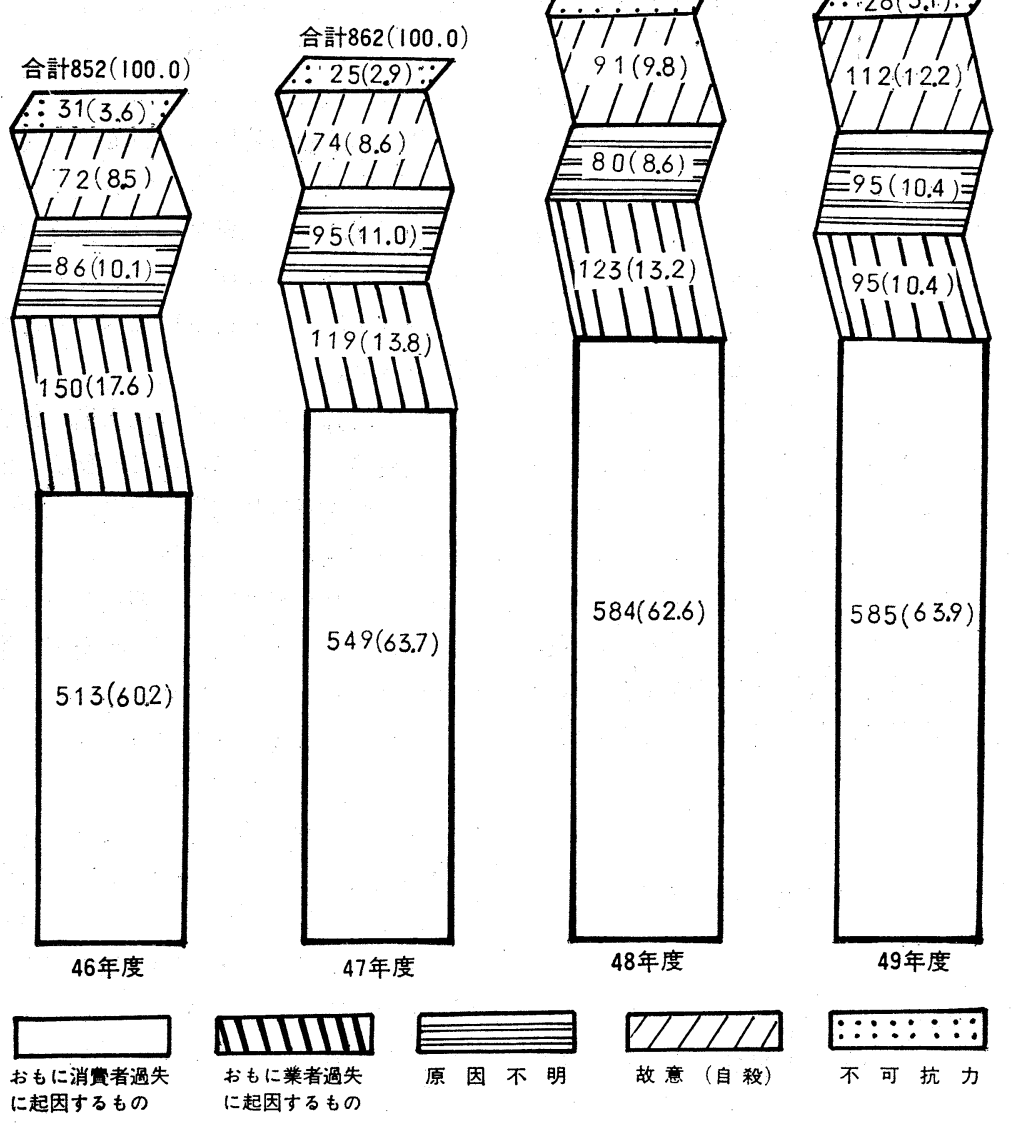

図 4-4 LP カスス事故件数の推移（件数，\%) 
業界は自ら率先して自主保安体制の確立にも全力をあ げている。

その具体的な現れとして, 先頃 LP ガスメーカー, 販売業者, 機器業者なぞ LP ガス 関係者が一致協力 して「家庭用 LP ガスの設備要領」を自主基準とし てまとめた。これは，LP ガス容器からふろがまや湯 沸器など燃焼器具までの設備機器の取り付けや，機器 使用の指導管理の基準を示したもので，今後，同要領 の基準が遵守され, 従来の設備が早急に同要領の水準 にまで格上げされるよう, 同要領の積極的活用が強く 望まれている。

また，LP ガス業界は同設備要領の発刊と併行し て,「LP ガスバルク供給設備および取扱要領」を発 効させた。

現在の LP ガスの消費形態には貯蔵タンクから配 管を敷き LP ガスを使用する方法と，LP ガスを一 本づつ容器詰めにし, その容器から LP ガスを取出 乙使用する方法とがある。このらち一般消費家庭など の小規模な消費者には, 容器詰めの消費形態が多くと られている。この点, 欧米諸国の LP ガス使用形態 をみると, あらかじめ必要な場所隹型の容器を設置 して扣き, その容器に専用のタンクローリから LP ガ スを充てんし，そこから配管供給する方式一バルク供 給方式一が一般的に普及している。この供給方式は優 れた数多くの利点をもち, 渾搬, 交換作業の省力化が はかられることに加え, 運搬時, 消費者の通常の取扱 い，地震時の事故防止などの安全面でも，とくに大き な効力を発揮する。ところが，わが国のバルク供給方 式については事業所や家庭の敷地面積の狭さなどか ら，北海道，北九州などの特定の地域でしかも工場な ぞの比較的規模の大きい消費者に限定されている。

「LP ガスバルク供給設備および取扱要領」はこう した背景に基づいてわが国注同方式が全国的規模 にまで普及するよう業界自主基準として作成したもの であり，今後の進捗状況に大きな期待が寄せられてい る。

\section{5 ガス化に関する研究}

\section{1. 固体燃料のガス化}

近い将来にエネルギー不足が予想されるため, 総合 的なエネルギー供給の内で化石燃料のガス化をとら兄 ようとする試みが盛んである。このような動きを反映 してアメリカに拈ける石炭ガス化の状況を紹介したも
の1) 6)，ヨーロッパの状況788)や日本の状況9)を解説し た総説などが発表された。酸素や水蒸気等を用いたが ス化反応を解説したもの ${ }^{10) 11)}$, 各種プロセスの技術を 比較したり新しい方式を紹介したもの ${ }^{12) ~ 20) な と ゙ か ゙ あ ~}$ った。その他プロセスの効率を検討したもの ${ }^{2122)}$ ガス 化発電について解説したもの ${ }^{23) 24)}$ など多くの総説25) 27)が発表された。

基礎的な研究としてはフラッシュ水素化の各反応因 子の影響を調べたもの ${ }^{28)}$, チャーと水蒸気の反応に拉 ける触媒作用を検討したもの ${ }^{29)}$ ， Rh が CO 生成反 応の選択性が高いことを明らかにしたもの ${ }^{30)}$, プラズ マジェットで石炭からアセチレン ${ }^{311}$, 水素や一酸化炭 素 ${ }^{32)}$ 造る研究や高温酸化雾囲気中でのコークスガス 化に関する研究 ${ }^{33)}$ な゙があった。数学的な取り扱いを したものとしては熱分解, 水素化反応のモデル ${ }^{34)}$, 加 圧化ガス化のモデル ${ }^{35)}$, ガス化の前処理工程としての 酸化反応の数学モデル ${ }^{36)}$ などがあった。その他高温核 反応装置からの熱を利用して流動層で石炭を水蒸気分 解する方法 ${ }^{37)}$ ，高温で He を熱供給に使い SNG を 製造する研究 ${ }^{38)}$, 地下ガス化テストプラントの結果に ついての報告 ${ }^{39}$ がみられた。また石炭ガス化に関連し た高温流動層の特性についての解説 40)やテストプラン トの問題点を述べたもの ${ }^{41}$ があった。変わったところ では石炭のガス化燃焼が直接燃焼方式より $\mathrm{NO}_{x}$ の生 成が少ないことを明らかにしたるの トが増えることによる環境への影響を検討したもの があった。

\section{2. 液体および気体炭化水素の分解, ガス化}

重質油のガス化についての解説は依然として多い。 昨年度は重質油分解技術の展望を解説したもの ${ }^{44)}$, 管 式熱分解法による灯軽油からのオレフィンの製造法に ついて記したもの ${ }^{45)}$, 呉羽法 ${ }^{46)}$ や $\mathrm{KK}$ 法 ${ }^{47)}$ について の解説やその他重質油利用技術一般 ${ }^{48)}$, 各種重質油ガ ス化プラントについて述べたるの

ガス化発電を考劣たプロセスの解説としてはシェル

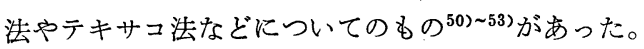

オレフィン製造の原料をより重質なるのに求める傾 向が強まるにつれ，その方面の研究す盛んになって いる。軽油の分解に扣けるオレフィン収率と BMCI (Bureau of Mines Correlation Index) と対応させ た研究 ${ }^{5455)}$, VGO などの分解における硫黄の問題を 検討したもの ${ }^{56)}$ があった。

基礎的な研究としては; エタン，プロパンなどのパ ラフィン存在下でシクロヘキサンを熱分解し，両パラ フィン炭化水素がシクロヘキサンの分解を促進するこ 
とを明らかにしたもの ${ }^{57)}$ ，電気アークによってメタ ン, 水素, $\mathrm{C}_{2}$ 炭化水素の混合ガスから”エチレンを造 る研究58)，プラズマジェットによりメタンリッチガス を水素に変換する研究 ${ }^{59}$ などがソビェトに扣いて精力 的に行なわれた。その他流動層を使った研究では重質 油の部分燃焼(0) と水蒸気改質 ${ }^{61)}$ があった。

\section{3. 水素, 合成ガス，都市ガスの製造を目的とする ガス化}

水素は単に化学反応用の原料としてだけではなく将 来のエネルギー源として期待されており, 最近は活発 飞研究されている。水素エネルギーの将来性について 検討したものとしては，様々な観点から他のエネルギ 一と比較してその重要性を指摘したもの ${ }^{622 \sim 64)}$, 水素 エネルギーシステム技術の現状と将来について解説し たもの ${ }^{65) ~ 67)}$, 水蒸気一鉄法, 水分解法等各種の ERDA

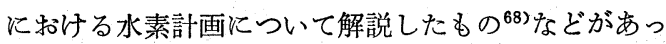
た。

炭化水素の水蒸気改質や部分酸化によって水素や合 成ガスを得る方法についての解説や研究は多い。水蒸 気改質触媒についての解説69), 重質油や石炭から合成 ガスや水素を製造する技術について解説したもの ${ }^{70)}$ ，

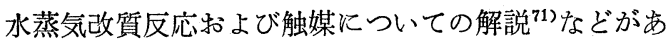
った。

基礎的な研究としては $\mathrm{Ni}-\mathrm{Al}_{2} \mathrm{O}_{3}$ 触媒によるナフ サの水蒸気改質に拈ける Ca の添加効果を ESR など を使って明らかにしたもの ${ }^{722}$, ポリアルミン酸カリウ 么触媒上に拈ける反応では $\mathrm{K}^{+}$が活性点になってい ることを明らかにした研究73)， $\mathrm{Ni}-\mathrm{Al}_{2} \mathrm{O}_{3}$ 触媒上に特 ける $\mathrm{n}$ 一ヘキサンやオクタンなどの 水蒸気分解の平衡 生成物についての研究 ${ }^{74)}$, 減圧残油を溶融塩で熱分解 して生成したコークスと水蒸気との反応のガス化速度 を求めた研究 75 などがあった。その他原子力ェネルギ 一を利用してメタンを水蒸気分解する研究 ${ }^{76) 77)}$ p $\mathrm{Li}$, $\mathrm{Na}, \mathrm{Mg}$ 等の水素化物之水の反応 ${ }^{78}$ p $\mathrm{MeO}+\mathrm{SO}_{2}+$ $\mathrm{H}_{2} \mathrm{O} \rightarrow \mathrm{MeSO}_{4}+\mathrm{H}_{2}$ なる反応で金属酸化物を使って水 素を製造する研究799などがあった。また水蒸気改質用 触媒の寿命予測法についての解説年方も西った。

都市ガス製造を目的とする研究としては，ナフサの 水蒸気分解反応の生成物予測法の研究 ${ }^{81)}, \mathrm{C}_{5} \sim \mathrm{C}_{8}$ 直 鎖パラフィンを $\mathrm{Ni}-\mathrm{Al}_{2} \mathrm{O}_{3}$ 触媒上で水素化分解し, 末端炭素の水素化脱メチルとは別の経路でェタン, プ ロパソへの分解反応が起こることを示した研究82883)な どがあった。

$$
\text { 文混 }
$$

1) G. Fumich Jr., Combustion, May, 7
2) R. T. Wallace, Chem. Eng., 83, (5),

3）吉田他，日本瓦斯協会誌，29，(1)，5

4) 同上

5) 同上

29, (2), 10

6) 同上

29, (3), 12

7) 同上

29, (4), 30

8) P.Ledent,

9) 渡辺, 科学々工業, 50, (6), 196

10) N. Berkowitz, Chem. Can., 28, (6), 23

11) 山村他, 化学総説, 12, 163

12) L. Sobolewski, Przem. Chem., 55, (1), 4

13) F. H. Franke, Waerme, 82, (3), 41

14) J. Kasperczyk, Stahl Eisen, 96, (15), 732

15) R.C.Patterson, Combustion, May, 28

16) J. Anwer, Brennst-Waerme-Kraft, 28, (2), 57

17) N. N.Ramakrishnan, Indian Chem. Manuf., 14, (2), 58

18) J. E. Franzen, Hydro. Process., 55, (11), 134

19) R. A. Sharpe, ibid., 55, (11), 171

20) 森田, 石油誌, $19,(3), 173$

21) D. A. Tillman, Erviron. Sci. Technol., 10, (1), 34

22) N.P. Cochran, Sci. Am., 234, (5), 24

23) M. Helmut, Proc. Ann. Conv.-Gas Process. Assoc. 55, 131

24) D. J. Ahner, Combustion, April, 26

25) K. A. Dollar, Proc. Annu. UMR-MEC conf. Energy 2nd, 65

26) H.R.Linden, Annu. Rev. Energy, 1, 65

27) P. Werner, Chem. Unserer Zeit, 10, (1), 10

28) R. A. Graff, Fuel, 55, (2), 109

29) N. Kayembe, ibid., 55, (3), 211

30) - J. Tashiro, ibid., 55, (3), 250

31) S.C.Chakravartty et al., Fuel, 55, (1), 43

32) T.W. Scott, Nature, 262, (5563), 48

33) И. д. Балон, Koks Khim, 7, 11

34) D. B. Anthony, Fuel, 55, (2), 121

35) B. Vaclav et al., Energietechnik, 26, (2), 71

36) A. Y. Kam, Chem. Eng. Sci., 31, (9), 815

37) P.P. Feistel et al., Erdoel Kohl Erdgas Petrochem, 29, (8), 350

38) F. Gabor, Energiagazdalkodas, 17, (3), 97

39) L. A. Schrider, Mech. Eng., 98, (3), 20

40）吉田, 燃協誌, 55, (1), 22

41）牧野他, 化学装置, 18, (3), 21

42) R. A. Lisauks et al., Chem. Eng. Progr., 72, (8), 76

43) C. E. Jahning et al., ibid., 72, (8), 51

44) 森田, 化学工学, 40, (7), 340

45) 佐藤, 同上, 40, (7), 347

46) 細井, 同上, 40, (7), 354

47) 国井, 同上, 40, (7), 358

48）功刀, 化学工業, 27, (12), 25

49) 橋本, 同上, 27, (12), 64

50) A. J. J. Van Ginneken et al., 石油誌, 19, (2), 123 
51) C. J. Kuhre, Oil Gas J., 74, (2), 110

52) E. T.Child et al., 石油誌, 19, (2), 134

53) S. A. Christianovich, World Pet. Congr. 9 th (6), 21

54) S. B.Zdonik et al., Hydro. Process., 55, (1), 149

55）同上, 55, (4), 161

56) M. A. Draaisma, Oil Gas J., 74, (31), 104

57) R. A. Kalinenko et al., Neftekhimiya, 16, (1) 100

58) M. V. Rozanova et al., Khim. Prom-st, (4), 261

59) A. V. Balotov et al., Gazov. Prom-st, (3), 38

60）佐々木他，三菱重工技報，13，(1)，106

61）森田他, 石油誌, 19, (4), 285

62) G. D. Sauter, World Hydrogen Energy Conf. 1st, (3), $1 \mathrm{C5}$

63) R. Nanvi et al., ibid., 1st (3), 3C3

64) L. W. Jones, ibid., 1st (3), 1C 61

65) 平野, 出光石油技術, 19, (2), 165

66) 同上, $19,(4), 434$

67) E. A. Laumann, World. Hydrogen Energy
Conf., 1st (3), 1C 45

68) A. R. Landgrebe, ibid., 1st (3), 1C 27

69）保原，出光石油技術， 19，(4)，1

70）中口, 燃協誌, 55, (8), 676

71）小谷川，北海道工業開発試験所技術資料 6 号

72) S. Banerjee et al., J. Res. Inst. Catal. Hokkaido Univ. 23, (1), 40

73) Kimura et al., Bull. Jap. Pet. Inst., 18, (2), 133

74) Gizella et al., Acta. Chem. Acad. Sci. Hung. $88,(3), 223$

75）水落他, 電力中央研究所報告, 275042

76）杉谷他，石川島播磨技報， 16, (2)，122

77) R. E. Harth et al., World Hydrogen Energy Conf., 1st (1), 1A3

78) P.S. Rudman et al., ibid., 1st (2), 3B31

79) R. Schuten et al., ibid., 1st (1), $1 \mathrm{~A} 19$

80）松本，触媒，18，(3)，71

81）馬場他，燃協誌，55，(3)，154

82）三木他，東京工業試験所報告，71，(12)，489

83）三木他, 日本化学会誌，(12)，1822

\section{Harry Marsh 博士講演会}

(University of New Castle upon Type, England, 上級講師)

\section{主催 日本化学会九州支部 \\ 共催 石油学会, 燃料協会}

\section{演 題製鉄コークスの品位とメソフェーズとの関連 \\ 日 時 10 月 12 日 (水) 午後 1 時 30 分 \\ 場 所 九州大学総合図書館視聴覚室 (福岡市東区箱崎)}

Marsh 博士は上記大学の Northern Coke Research Laboratories の上級研究員として 炭素材・コークスの生成反応について幅広い研究を逐行され，炭化反応の世界的権威のひと りとして著名で，国際学術誌 “Corbon” Fuel (London) の編集員の一員として国際的に活 躍中の現役の研究者です。今回北大真田教授をホストに学術振與会の招待教授として来日さ れ九州地方に 1 週間滞在されます。この機会に炭化反応に関する講演を和願い致しました。 奮ってご出席下さい。 